\title{
Submarine giant pumice: a window into the shallow conduit dynamics of a recent silicic eruption
}

\author{
Samuel J. Mitchell ${ }^{1,2}$ (D) $\cdot$ Bruce F. Houghton ${ }^{2} \cdot$ Rebecca J. Carey $^{3} \cdot$ Michael Manga $^{4} \cdot$ Kristen E. Fauria $^{4,5}$. \\ Meghan R. Jones ${ }^{5}$. S. Adam Soule ${ }^{5} \cdot$ Chris E. Conway $^{6} \cdot$ Zihan Wei $^{4,7} \cdot$ Thomas Giachetti $^{8}$
}

Received: 24 September 2018 / Accepted: 12 May 2019 / Published online: 20 June 2019

(C) The Author(s) 2019

\begin{abstract}
Meter-scale vesicular blocks, termed "giant pumice," are characteristic primary products of many subaqueous silicic eruptions. The size of giant pumices allows us to describe meter-scale variations in textures and geochemistry with implications for shearing processes, ascent dynamics, and thermal histories within submarine conduits prior to eruption. The submarine eruption of Havre volcano, Kermadec Arc, in 2012, produced at least $0.1 \mathrm{~km}^{3}$ of rhyolitic giant pumice from a single 900 -m-deep vent, with blocks up to $10 \mathrm{~m}$ in size transported to at least $6 \mathrm{~km}$ from source. We sampled and analyzed 29 giant pumices from the 2012 Havre eruption. Geochemical analyses of whole rock and matrix glass show no evidence for geochemical heterogeneities in parental magma; any textural variations can be attributed to crystallization of phenocrysts and microlites, and degassing. Extensive growth of microlites occurred near conduit walls where magma was then mingled with ascending microlite-poor, low viscosity rhyolite. Meter- to micron-scale textural analyses of giant pumices identify diversity throughout an individual block and between the exteriors of individual blocks. We identify evidence for post-disruption vesicle growth during pumice ascent in the water column above the submarine vent. A 2D cumulative strain model with a flared, shallow conduit may explain observed vesicularity contrasts (elongate tube vesicles vs spherical vesicles). Low vesicle number densities in these pumices from this high-intensity silicic eruption demonstrate the effect of hydrostatic pressure above a deep submarine vent in suppressing rapid late-stage bubble nucleation and inhibiting explosive fragmentation in the shallow conduit.
\end{abstract}

Keywords Giant pumice $\cdot$ Submarine volcanism $\cdot$ Banding $\cdot$ Tube pumice $\cdot$ Bubble deformation $\cdot$ Conduit dynamics

Editorial responsibility: K.V. Cashman

Electronic supplementary material The online version of this article (https://doi.org/10.1007/s00445-019-1298-5) contains supplementary material, which is available to authorized users.

Samuel J. Mitchell

sm1645@my.bristol.ac.uk

1 School of Earth Sciences, University of Bristol, Wills Memorial Building, Queens Rd, Bristol BS8 1RJ, UK

2 Department of Earth Sciences, University of Hawai'i at Mānoa, POST 606, 1680 East-West Rd, Honolulu, HI 96822, USA

3 School of Natural Sciences, University of Tasmania, Hobart, Tasmania 7001, Australia

4 Department of Earth and Planetary Science, University of California, Berkeley, McCone Hall, Berkeley, CA 94709, USA
5 Department of Geology \& Geophysics, Woods Hole Oceanographic Institution, Woods Hole, MA 02543, USA

6 Institute of Earthquake and Volcano Geology, Geological Survey of Japan, AIST, Central 7, 1-1-1, Higashi, Tsukuba, Ibaraki 305-8567, Japan

7 School of Earth, Energy \& Environmental Sciences, Stanford University, Stanford, CA 94305, USA

8 Department of Earth Sciences, University of Oregon, 100 Cascade Hall, Eugene, OR 97403-1272, USA 


\section{Introduction}

Voluminous deposits of giant pumiceous blocks up to meters across ("giant pumice") are more commonly associated with submarine silicic eruptions than subaerial eruptions, and can be found throughout the subaqueous volcaniclastic record (Allen and McPhie 2009; Allen et al. 2010; Kano et al. 1996; Kano 2003; Manga et al. 2018a; Risso et al. 2002; Von Lichtan et al. 2016). They are observed (1) in uplifted ancient sequences with interpreted subaqueous provenance, (2) on the modern seafloor, or (3) on fossil lake shores from sublacustrine volcanic eruptions (Allen and McPhie 2009; Barker et al. 2012; Carey et al. 2018; Houghton et al. 2010; Risso et al. 2002). Subaqueous rhyolitic giant pumices have been studied in detail at Lake Taupo, New Zealand, from the 1.8-ka Taupo eruption (Houghton et al. 2010; Von Lichtan et al. 2016; White et al. 2001), the Sumisu Domes on the Izu-Bonin arc (Allen et al. 2010), and in other locations of various water depths, although in less detail (Kano 2003; Risso et al. 2002). These giant pumices are many meters in size, have blocky euhedral faces, can have vesicularities up to $80 \%$, and in both the Taupo and Sumisu cases, the blocks are associated with large, pumiceous subaqueous domes (Allen et al. 2010; Houghton et al. 2010).

Multidisciplinary analytical studies have been conducted for decades on pumice from subaerial silicic eruptions to infer shallow conduit dynamics and processes of volatile exsolution from the host melt (e.g., Burgisser et al. 2017; Carey et al. 2009; Eichelberger and Westrich 1981; Giachetti et al. 2010; Houghton et al. 2010; Janebo et al. 2016; Klug et al. 2002; Polacci et al. 2001; Polacci et al. 2004; Polacci et al. 2006; Shea et al. 2010; Whitham and Sparks 1986; Wilson 1993; Wright et al. 2003, 2006). Quantitative information such as vesicle number densities, vesicle volume distributions, permeability, and vesicle connectivity is commonly extracted from studies of vesicular microtextures. In combination with geochemical data and models for magma ascent, these data can be used to understand bubble nucleation, bubble coalescence, magma decompression rates, and outgassing in the conduit.

Similar techniques have been, and can be, applied to deposits in the submarine environment to reveal the effect of high hydrostatic pressure from the overlying ocean, which provides a fundamental control on the production of pumiceous clasts (Allen et al. 2010; Barker et al. 2012; Cas and Giordano 2014; Cas and Simmons 2018; Head and Wilson 2003; Jones et al. 2018; Murch et al. 2019; Rotella et al. 2015; Schipper et al. 2010a, 2010b, 2010c; Von Lichtan et al. 2016; White et al. 2015). Explosive fragmentation of magma in conduits is thought to occur at very shallow-depth subaqueous vents or at sufficiently high decompression and strain rates (Cashman and Scheu 2015; Manga et al. 2018a). Nonexplosive mechanisms include the spalling of hot, vesicular subaqueous dome carapaces (Allen et al. 2010; Houghton et al. 2010), slow, buoyant detachment of hot, vesicular magma bodies (Rotella et al. 2013; Shea et al. 2013), or the rapid propagation of cooling joints through a rapidly ascending magma body within the water column (Manga et al. 2018a; Van Otterloo et al. 2015). Limited understanding of the fragmentation mechanisms results from the lack of direct observations of submarine silicic eruptions.

One benefit of analyzing giant pumice is the preservation of meter-scale variations in texture, providing a larger, intact window into the dynamics of magma ascent and fragmentation than is possible when using smaller lapilli. This also allows us to assess the role of hydrostatic pressure control on magma decompression. A giant pumice unit (GP) from the 2012 eruption of Havre submarine volcano, Kermadec Arc, has a moderately well-constrained mass eruption rate and vent depth (Carey et al. 2018; Manga et al. 2018a, b). This study presents detailed textural and geochemical analyses of giant pumice from this eruption and provides a quantitative bridge between observations and inferred physical processes within a submarine silicic conduit.

\section{Giant pumice from the 2012 Havre eruption}

The 2012 eruption of Havre volcano on the Kermadec Arc, New Zealand, was the largest recorded, deep submarine silicic eruption for 360 years prior to the eruption date (Carey et al. 2014; Rotella et al. 2015). More than $1.5 \mathrm{~km}^{3}$ of rhyolite (70$72 \mathrm{wt} . \% \mathrm{SiO}_{2}$ ) erupted, at vent depths of $650-1280 \mathrm{~m}$, with most of the volume being erupted from one $900 \mathrm{~m}$ deep vent (Carey et al. 2014, 2018). A deposit of giant pumiceous blocks, which stacked up to five clasts high, covers > $36 \mathrm{~km}^{2}$ of the caldera floor to at least $6 \mathrm{~km}$ from the vent (unit GP). The calculated volume in this sector is $0.1 \mathrm{~km}^{3}$, which is a minimum as the deposit extends further than the mapped area (Carey et al. 2018). A $0.11-\mathrm{km}^{3}$ rhyolitic dome pairDome OP (P on top of $\mathrm{O}$ ) - now overlies the vent responsible for the pumice raft and GP deposit (Fig. 1). The seafloor GP deposit is inferred to be genetically related to the production of a pumice raft that formed over a 21.5 -h period on July 18 , 2012 (Carey et al. 2018; Jutzeler et al. 2014). Assuming a synchronous, linked origin, the time-averaged mass eruption rate estimated for this eruptive phase is $\sim 10^{7} \mathrm{~kg} \mathrm{~s}^{-1}$ (Carey et al. 2018).

Clast diameters, based on Remotely Operated Vehicle (ROV) observation, average 1-2 $\mathrm{m}$ and increase with distance from the vent; the largest observed clasts are $9 \mathrm{~m}$ in diameter (Carey et al. 2018). Giant pumices display a range of clastscale textures: sub-rounded to angular shapes, exterior fabrics with preferred lineation of textures, angular curvi-planar exteriors, deep fractures within entire clasts, and rare breadcrusted exteriors (Fig. 1). 

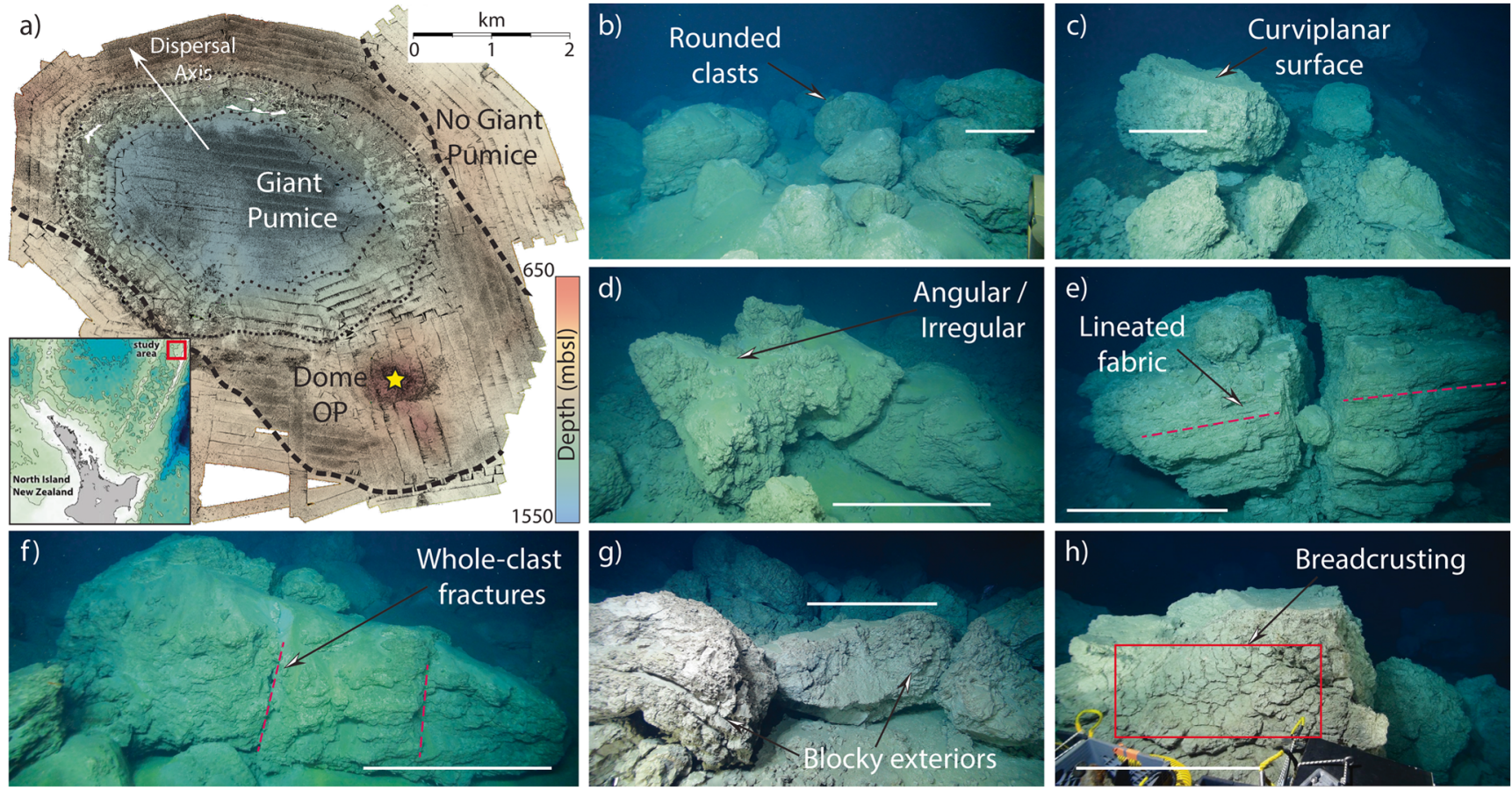

Fig. 1 Characteristics of the unit GP from the 2012 Havre eruption. (a) Shows the distribution of unit GP across the Havre caldera, inferred as "rougher" seafloor from high-resolution (1 m) AUV bathymetry and roughness data. A clear interface between rough and smooth seafloor outlines the boundary of the GP unit (dashed line); the proposed vent

A 1D conduit ascent model for Havre 2012 eruption conditions and magma type is compatible with fragmentation above, and not below, the vent (Manga et al. 2018a). The inferred dissolved magmatic water concentration at $900 \mathrm{~m}$ depth (up to $1.0 \mathrm{wt} \%$ at $9.2 \mathrm{MPa}$ hydrostatic pressure) would have kept the melt viscosity low enough that the strain rate fragmentation threshold (Gonnermann and Manga 2003; Papale 1999) was not reached before extrusion into the ocean (Manga et al. 2018a).

\section{Analytical methods}

The pumiceous exteriors of 29 individual giant pumices, and one intact $1.5 \times 1 \times 1 \mathrm{~m}$ giant pumice (sample GP290), were collected with the ROV Jason in 2015 (Carey et al. 2018). Exterior samples were broken off the surfaces of giant pumices using the Jason manipulator. Sample GP290, the $1.5 \mathrm{~m}^{3}$ intact giant pumice recovered from the seafloor $1.4 \mathrm{~km}$ from the main vent, serves as our meter-scale window into magma textural diversity; GP290 was the only whole giant pumice collected from the seafloor due to limitations associated with sampling large volumes and masses using an ROV. In this study, we use "exterior fragments" to refer to pieces of individual giant pumice exteriors broken during seafloor sampling. Exterior fragments up to $30 \mathrm{~cm}$ across were examined and locality under Dome OP is given by the star symbol (Carey et al. 2018). The location of the Havre caldera along the Kermadec Arc is given in the inset. Examples of GP blocks are given in (b) through (f) highlighting a variety of morphological and textural characteristics. A 1-m scale bar is given in each image for the relevant clast

classified by their dominant macrotextural characteristics from a subset of 26 individual giant pumices; 10 were then selected for more detailed density, microtextural, and geochemical analysis. Exterior fragments were classified either as banded, regular (lack of banding or significant vesicle shearing), or tube (pumices with dominantly tube vesicles; see online resource 1 for details). The 10 selected were representative of the 26 in this textural classification.

\section{Whole rock and glass geochemistry}

X-ray fluorescence analyses (XRF) of crushed whole-rock samples determined the major, minor, and trace element concentrations of the bulk magma composition of 10 pumice clasts, as well as gray and white bands from GP290; XRF analyses used a Rigaku RIX1000 (see Online Resource 2 for XRF analysis details). Major and minor element concentrations of matrix glass and phenocrysts (plagioclase and orthopyroxene-Carey et al. 2018) were analyzed using a JEOL JXA-8500F microprobe analyzer with a fieldemission electron gun at $15 \mathrm{keV}$ accelerating voltage with a $10-n A$ beam current and spot sizes of $10 \mu \mathrm{m}$ (see Online Resource 3 for EPMA count times). Microlites were too small to gain accurate, reliable EPMA measurements using the same measurement techniques. 


\section{Density and 2D microtextural analysis}

We measured density/vesicularity from between 4 and 100 fragments $(8-32 \mathrm{~mm}$ in diameter) each from the 10 select larger exterior samples following the methods of Houghton and Wilson (1989). We then selected representative clasts for thin section and geochemical analysis using a dense rock equivalent density of $2380 \mathrm{~kg} \mathrm{~m}^{-3}$, determined by crushing pumice samples to powders (see Online Resource 1). Backscattered electron (BSE) images of thin sections were acquired at $\times 50, \times 250$, and $\times 500$ magnification for vesicles and at $\times 250, \times 500$, and $\times 1000$ for microlites using the microprobe at $15 \mathrm{keV}$ with an 8 -nA beam current (see Online Resource 2 for image processing).

Vesicle number densities per area $\left(\mathrm{N}_{\mathrm{A}}\right)$, vesicle area distributions (VADs) of vesicles $2.4 \mu \mathrm{m}$ to $3.78 \mathrm{~mm}$ in diameter were acquired from binary-processed BSE images and scans following Shea et al. (2010). Shape parameters of circularity, roundness, regularity, and solidity were also acquired for all vesicles $>19 \mu \mathrm{m}$ in diameter (vesicle shape analysis is given in online resource 4). Parameters $\mathrm{N}_{\mathrm{A}}$ and VADs were then converted into corrected number densities per volume $\left(\mathrm{N}_{\mathrm{Vm}}\right)$ and volume distributions (VVDs) assuming spherical vesicle geometries as per the methods of Sahagian and Proussevitch (1998) (see Online Resource 4 for stereo-conversion details). Vesicles in BSE images were manually decoalesced; the subjectivity of the method increases the credibility of the obtained $\mathrm{N}_{\mathrm{V}}$ values (see Online Resource 4). The stereo-conversion of elongate, tube, and sheared vesicles uses a modification of the Sahagian and Proussevitch (1998) method (see Appendix 1). Microlite number densities per area $\left(\mathrm{mN}_{\mathrm{A}}\right)$ were determined from counting microlites in BSE images where $\mathrm{mN}_{\mathrm{A}}$ values were corrected for image vesicularity to obtain microlites per melt area $\left(\mathrm{mN}_{\mathrm{Am}}\right)$.

\section{D textural analysis}

A $0.8 \times 0.4 \times 0.4 \mathrm{~m}$ fragment from the half of the intact $1.5 \mathrm{~m}$ wide giant pumice clast (GP290) was scanned at $0.165 \mathrm{~mm} /$ voxel resolution using $\mathrm{X}$-ray computed tomography. Two small cores $\left(<10 \mathrm{~mm}^{3}\right)$ from GP290 and from two other Havre seafloor pumice from the 2012 eruption were imaged at 0.61 and $1.22 \mu \mathrm{m} /$ voxel resolution using X-ray computed microtomography ( $\mu \mathrm{XRT}$ ). Scans were used to obtain vesicle aspect ratios and vesicle orientation in samples with either spherical or elongate vesicles (see Online Resource 5 for method details). However, we use the 2D data to acquire vesicle volume distributions due to a larger vesicle size range and the presence of artifacts in the $3 \mathrm{D}$ analysis.

Cylindrical cores $\left(2-10 \mathrm{~cm}^{3}\right)$ were extracted from 26 giant pumice exteriors to determine connected porosity and permeability $(k) ; 27$ GP290 cores were used to assess textural diversity within a single giant pumice. Cores with tube vesicles were acquired in orientations parallel and perpendicular to the elongation axis. The Darcian $\left(k_{1}\right)$ and inertial $\left(k_{2}\right)$ permeability of cylindrical cores were determined using a PMI CFP34RUE8A-3-6 Capillary Flow Porometer. Values for $k_{1}$ and $k_{2}$ were fitted to the Forchheimer equation over a range of flow rates (Degruyter et al. 2012):

$\frac{\Delta P}{L}=\frac{\mu_{g}}{k_{1}} U+\frac{\rho_{g}}{k_{2}} U^{2}$

where $\Delta P$ is pressure difference over the core, $L$ is core length, $U$ is flow rate determined from the outgassing velocity and core cross-sectional area, $\rho_{g}$ is air density $1.2 \mathrm{~kg} \mathrm{~m}^{-3}$, and $\mu_{\mathrm{g}}$ is gas viscosity $\left(10^{-5} \mathrm{~Pa} \mathrm{~s}\right)$ as taken from Degruyter et al. (2012).

Vesicle connectivity was determined for cores and noncylindrical fragments of samples that were too fragile to core. We measured the porosity of 61 fragments, 52 of which had cylindrical geometries suitable for permeability analysis. Total porosity $\left(\phi_{t}\right)$ and connected porosity $\left(\phi_{c}\right)$ of cores/fragments were determined using an AccuPyc II 1340 Gas Pycnometer. Connectivity $(c)$ was quantified as the ratio $\phi_{c} / \phi_{t}$.

Finally, we use microtextural data obtained from this study to calculate magma decompression rates (following Toramaru et al. (2008) and Brugger and Hammer (2010a)) and set up a $2 \mathrm{D}$ conduit ascent model. This new model builds on the results obtained from the 1D model by Manga et al. (2018a), and assesses strain conditions within the shallow conduit during the 2012 Havre eruption (model details and parameters are given within Appendix 2).

\section{Results}

\section{Geochemistry of Havre giant pumices}

The whole-rock major element compositions of giant pumice samples are consistent with those previously reported for the pumice raft and Dome OP from the 2012 Havre eruption (Carey et al. 2018; Rotella et al. 2015) (Fig. 2). Giant pumice samples analyzed have a narrow $\mathrm{SiO}_{2}$ range of 71.9$72.3 \mathrm{wt} . \%$ (normalized to $100 \mathrm{wt} . \%$ ) where all major elements are within $8 \%$ relative standard deviation (RSD) and with no variation between individual samples (Table 1). Similarly, there is little variation in trace element geochemistry with statistical differences only for $\mathrm{S}$ and $\mathrm{Cu}$, though there is no statistical correlation between the two. There is no bulk geochemical variation between adjacent white and gray bands from GP290 (see Online Resource 2).

There are greater geochemical variations within matrix glasses than between the bulk compositions of giant pumices (Table 1). The $\mathrm{SiO}_{2}$ range increases to $74.1-75.5 \mathrm{wt} . \%$ where the more evolved glass compositions are found within gray 


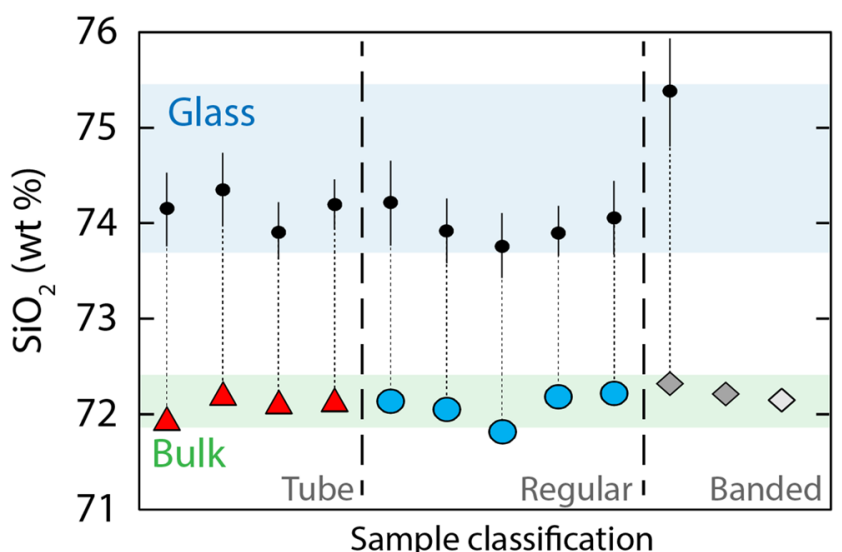

Fig. 2 Major element $\mathrm{SiO}_{2}$ variation between bulk whole rock and matrix glass for each pumice sample in every textural classification: tube (red triangle), regular (blue circle), banded (gray - gray band, and whiteadjacent white pumice, diamonds). The green box gives the whole rock range of raft pumice and Dome OP from Rotella et al. (2015) and Carey et al. (2018). Matrix glass error of 10 measurements given by $\pm 1 \mathrm{SD}$ error (solid black line) for each data point. XRF (bulk) error is smaller than the symbols used banding (GP290), even when directly adjacent to white bands (Fig. 2, Online Resource 4). We can attribute major element variations in glass to the crystallization of the observed phenocryst and additional microlite phases resulting in a more evolved glass composition (see Online Resource 2 \& Online Resource 6). The lack of significant or consistent variation in major and/or incompatible trace elements between giant pumices and previous XRF analyses indicates a chemically homogeneous GP magma source with no evidence for mixing with a second, geochemically distinct magma.

\section{Textural results}

There is no observable variation in giant pumice vesicularity with distance from source, although full assessment is limited by the number and spatial distribution of samples (see Online Resource 1). Giant pumice clast exteriors (including GP290) were classified into three main groups: regular, tube, and banded based on macroscale observations (Fig. 3).

Table 1 XRF whole rock and EPMA glass (italics) major element geochemistry for GP samples after normalization to $100 \mathrm{wt} . \%$. Samples are defined by their HVR_ sample number and macrotextural classification. Iron is corrected to $\mathrm{FeO}_{\mathrm{t}}$ from $\mathrm{Fe}_{2} \mathrm{O}_{3}$ (XRF analysis only)

\begin{tabular}{|c|c|c|c|c|c|c|c|c|c|c|c|c|c|}
\hline \multirow{2}{*}{$\frac{\text { Group }}{\text { HVR_ }}$} & \multicolumn{5}{|l|}{ Regular } & \multicolumn{4}{|l|}{ Tube } & \multicolumn{3}{|c|}{ Banded } & \multirow{2}{*}{$\frac{\% \mathrm{RSD}^{* *}}{\mathrm{All}}$} \\
\hline & 041 & 096 & 192 & 221 & 231 & 003 & 022 & 115 & 270 & 290 & 290_Gray & 290_White & \\
\hline \multirow[t]{2}{*}{$\mathrm{SiO}_{2}$} & 72.07 & 72.02 & 71.85 & 72.15 & 72.21 & 71.95 & 72.18 & 72.09 & 72.11 & 72.34 & 72.17 & 72.11 & 0.17 \\
\hline & 74.12 & 73.92 & 73.76 & 73.89 & 74.05 & 74.15 & 74.35 & 73.90 & 74.19 & 75.38 & - & - & 0.59 \\
\hline \multirow[t]{2}{*}{$\mathrm{TiO}_{2}$} & 0.48 & 0.47 & 0.50 & 0.46 & 0.45 & 0.47 & 0.46 & 0.46 & 0.49 & 0.51 & 0.51 & 0.51 & 4.45 \\
\hline & 0.38 & 0.37 & 0.41 & 0.36 & 0.39 & 0.38 & 0.40 & 0.40 & 0.38 & 0.46 & - & - & 6.74 \\
\hline \multirow[t]{2}{*}{$\mathrm{Al}_{2} \mathrm{O}_{3}$} & 14.16 & 14.24 & 14.16 & 14.14 & 14.09 & 14.22 & 14.05 & 14.18 & 14.10 & 13.98 & 14.09 & 14.08 & 0.50 \\
\hline & 13.88 & 13.87 & 13.89 & 13.94 & 14.01 & 13.90 & 13.87 & 13.88 & 13.92 & 13.09 & - & - & 1.80 \\
\hline \multirow[t]{2}{*}{$\mathrm{FeO}_{\mathrm{t}}$} & 3.05 & 3.05 & 3.11 & 3.04 & 3.01 & 3.06 & 3.02 & 3.04 & 3.05 & 2.99 & 3.06 & 3.03 & 0.94 \\
\hline & 2.44 & 2.51 & 2.57 & 2.43 & 2.41 & 2.53 & 2.36 & 2.45 & 2.40 & 2.42 & - & - & 2.51 \\
\hline \multirow[t]{2}{*}{$\mathrm{MnO}$} & 0.12 & 0.12 & 0.12 & 0.12 & 0.12 & 0.12 & 0.12 & 0.12 & 0.12 & 0.12 & 0.12 & 0.12 & Negligible \\
\hline & 0.11 & 0.11 & 0.11 & 0.10 & 0.11 & 0.11 & 0.11 & 0.10 & 0.11 & 0.11 & - & - & 3.70 \\
\hline \multirow[t]{2}{*}{$\mathrm{MgO}$} & 0.71 & 0.67 & 0.89 & 0.69 & 0.74 & 0.80 & 0.73 & 0.77 & 0.78 & 0.70 & 0.71 & 0.72 & 7.76 \\
\hline & 0.37 & 0.44 & 0.46 & 0.37 & 0.36 & 0.44 & 0.35 & 0.42 & 0.38 & 0.34 & - & - & 10.4 \\
\hline \multirow[t]{2}{*}{$\mathrm{CaO}$} & 2.64 & 2.67 & 2.67 & 2.60 & 2.59 & 2.66 & 2.58 & 2.63 & 2.63 & 2.54 & 2.56 & 2.60 & 1.57 \\
\hline & 2.09 & 2.13 & 2.20 & 2.07 & 2.09 & 2.13 & 1.95 & 2.13 & 2.04 & 1.64 & - & - & 7.30 \\
\hline \multirow[t]{2}{*}{$\mathrm{Na}_{2} \mathrm{O}$} & 5.07 & 5.17 & 4.97 & 5.16 & 5.17 & 5.05 & 5.20 & 5.08 & 5.03 & 5.01 & 5.09 & 5.14 & 1.37 \\
\hline & 4.68 & 4.75 & 4.75 & 4.94 & 4.77 & 4.55 & 4.80 & 4.91 & 4.74 & 4.56 & - & - & 2.54 \\
\hline \multirow[t]{2}{*}{$\mathrm{K}_{2} \mathrm{O}$} & 1.61 & 1.49 & 1.63 & 1.55 & 1.52 & 1.58 & 1.58 & 1.55 & 1.61 & 1.73 & 1.61 & 1.61 & 3.68 \\
\hline & 1.61 & 1.63 & 1.58 & 1.63 & 1.57 & 1.54 & 1.57 & 1.56 & 1.58 & 1.75 & - & - & 3.54 \\
\hline \multirow[t]{2}{*}{$\mathrm{P}_{2} \mathrm{O}_{5}$} & 0.09 & 0.09 & 0.09 & 0.08 & 0.09 & 0.09 & 0.08 & 0.08 & 0.09 & 0.08 & 0.08 & 0.08 & 5.88 \\
\hline & 0.03 & 0.05 & 0.06 & 0.06 & 0.04 & 0.06 & 0.05 & 0.05 & 0.05 & 0.06 & - & - & 18.5 \\
\hline \multirow[t]{2}{*}{$\mathrm{S}^{*}$} & 41 & 29 & 63 & 76 & 59 & 62 & 61 & 54 & 36 & 172 & 74 & 93 & 52.1 \\
\hline & 26 & 48 & 23 & 55 & 15 & 31 & 9.0 & 51 & 20 & 3.1 & - & - & 60.7 \\
\hline \multirow[t]{2}{*}{$\mathrm{Cl}$} & - & - & - & - & - & - & - & - & - & - & - & - & - \\
\hline & 0.19 & 0.22 & 0.22 & 0.20 & 0.19 & 0.19 & 0.19 & 0.19 & 0.20 & 0.21 & - & - & 5.92 \\
\hline
\end{tabular}

All glass geochemistry given in italics

* $S$ values given in ppm, all other values given in wt $\%$

$* * \%$ relative standard deviation of specific element concentration across all giant pumice exteriors 

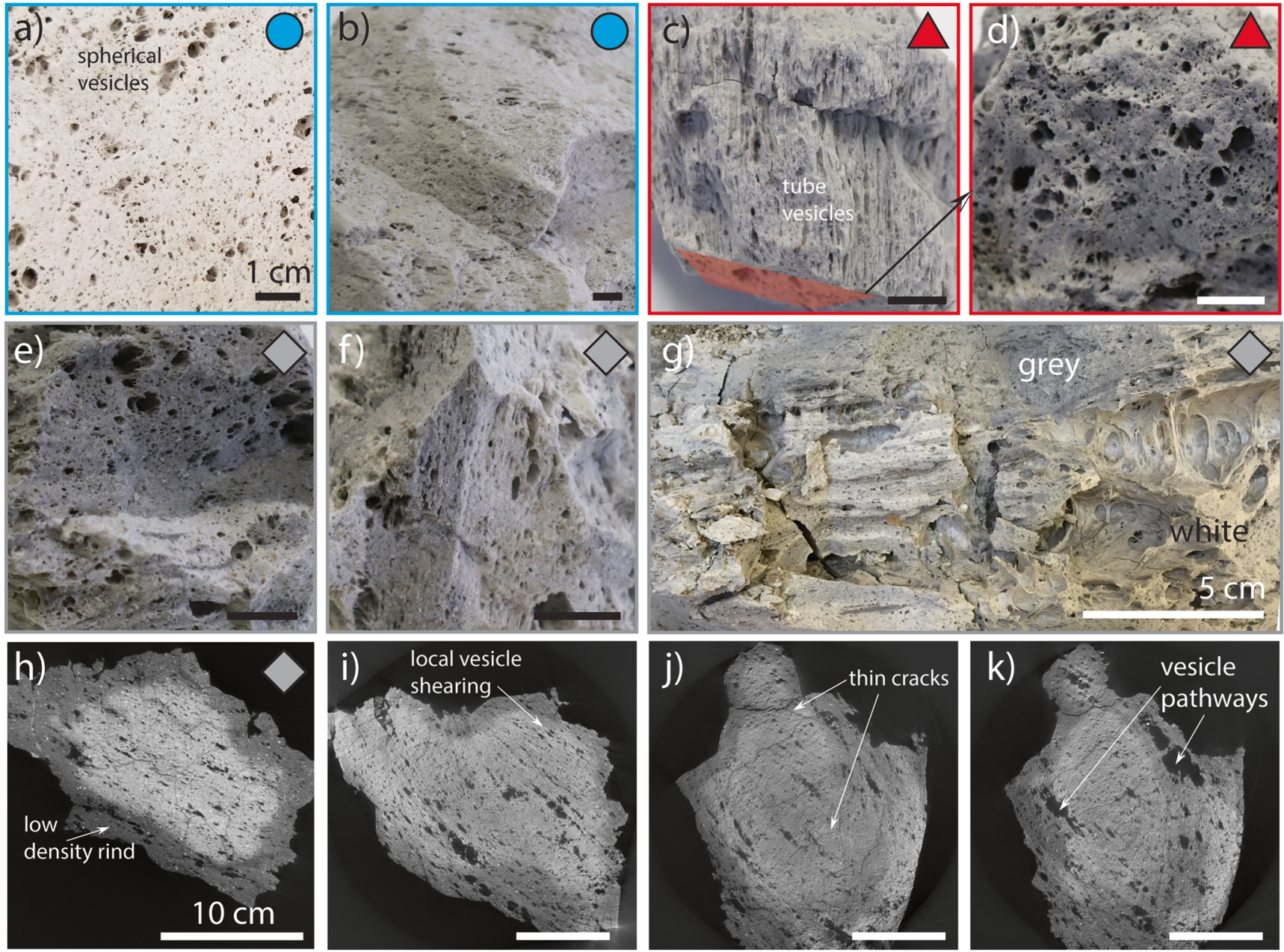

Fig. 3 Macrotextural classification of giant pumice fragments and large scan images. Regular pumices given in (a) and (b). Tube pumices are given both normal (c) and parallel (d) to the elongate vesicle orientation. Gray and white bands in giant pumice GP290 have sharp interfaces

Regular giant pumice fragments have average vesicularities of $68-89 \%$, tube giant pumice fragments have $62-88 \%$, and banded giant pumice fragments are $64-84 \%$. There is little evidence from macroscale observations for collapsed degassing pathways or magma compaction in any of the giant pumice samples (Burgisser et al. 2017; Rust and Cashman 2004; Saar and Manga 1999).

Regular clasts are dominated by round vesicles with a lack of elongate/tube vesicles and show no banding. There is also variability between individual regular giant pumices where large, $\mathrm{cm}$-size vesicle populations dominate some samples but not others (Fig. 3a, b). Elongate vesicles with near circular cross sections dominate tube pumices where tube vesicles may cut through the entire clast (e.g., Fig. 3c, d). Banded pumices display a similar macrovesicular texture to the regular samples and lack tube vesicles, although some stretched vesicles are present. There are two forms of banding in giant pumices. First, we observe thin (mm-scale) sinuous banding with slight color variation. Thin banding is defined by

between bands (e-g). Images (a) through (f) are given with a 1-cm scale bar and corresponding symbology to Fig. 2. Images (h) to (k) show 2D slices through the large GP290 scan. Images all have $10 \mathrm{~cm}$ scale bars. Key textural features are identified in scan images

localized regions that appear slightly darker in hand samples with a lack of vesiculation seen in BSE images (see Online Resource 7). A second type of banding contains $\mathrm{cm}-$ wide darker gray bands with sharp boundaries with adjacent white bands of similar density (Fig. 3e-g). Out of 29 giant pumices analyzed, only GP290 displays the second form of banding (Fig. 3e-g).

\section{Whole-clast textural heterogeneity in GP290}

The 3D CT scan of a large fragment from GP290 shows variations in the abundance of $\mathrm{mm}$ to $\mathrm{cm}$-size vesicles, and reveals large, $5-10 \mathrm{~cm}$ vesicles that we cannot see in thin section or small fragments (Fig. 3h-k). Vesicles with diameters < $500 \mu \mathrm{m}(\sim 3 \times$ pixel resolution) are not resolved in the coarse-resolution CT scan. There is a darker, lower density rind (85-90\% vesicularity and $<4 \mathrm{~cm}$ thick) on the exterior portions of the pumice fragment enclosing a heterogeneously vesicular interior (Fig. 3h). Permeable pathways that connect 
the top and bottom of the scanned fragment are up to a few $\mathrm{cm}$ across and run throughout the fragment but have no preferred orientation relative to the exterior surfaces, e.g., radial from the center. There is no visible change in the abundance of large $1-5 \mathrm{~cm}$ diameter vesicles away from the exterior. There are also small, randomly oriented zones of shearing up to $5 \mathrm{~cm}$ across, but adjacent non-sheared regions are not marked by sharp textural interfaces. Banding is difficult to distinguish with the CT scan due to a lack of density contrast between gray and white bands, but visual observations suggest that even though bands may run parallel through the clast, there is little preferred orientation relative to the exterior surfaces.

These observations (reflected in other fragments of GP290) reveal the textural heterogeneity captured within a single meter-sized giant pumice clast (Carey et al. 2018). Sample GP290 appears to show greater textural diversity (banding and vesicle size distributions) compared to the other 28 block exteriors sampled. However, the largest of these 28 exterior pieces was $<40 \mathrm{~cm}$ across so we are not able to observe the full textural diversity in other giant pumices as we do in GP290.

\section{Permeability and vesicle connectivity}

There is no systematic distinction in permeability between the pumice textural types (banded, tube, regular) (Fig. 4a, b; see Online Resource 8 for all data). Darcian permeability $\left(k_{1}\right)$ varies across all giant pumice exteriors $\left(5 \times 10^{-13}\right.$ to $\left.2 \times 10^{-9} \mathrm{~m}^{2}\right)$; GP290 $k_{1}$ values span a narrower range $\left(5 \times 10^{-13}\right.$ to $\left.10^{-11} \mathrm{~m}^{2}\right)$. The broad range is expected for pumices with high vesicularity and coalesced vesicles where the highest $k_{1}$ values resulting from large vesicles within cores (Degruyter et al. 2012). There is no correlation between connected porosity and permeability, and all $k_{1}$ values for GP lie outside of the region defined as "effusive" for subaerial magma (Degruyter et al. 2012) despite the inferred "non-explosive" fragmentation of GP magma (Manga et al. 2018a, b). Most $k_{1}$ values lie within the "explosive" region. However, the $k_{2}$ (inertial) values lie mostly outside of either field potentially expanding the field of Degruyter et al. (2012) defined for explosive eruptions (Fig. 4b). There is no consistent variation in permeability between cores taken parallel and perpendicular to the vesicle orientation (see Online Resource 8). The high permeability values, very high total porosity, and connectivity (Fig. 4) limit vesicle orientation controls on permeability. This is in agreement with Wright et al. (2009) who showed, inversely, that vesicle orientation was more prevalent in magmas with lower porosity and permeability.

There is a clear increase in connectivity $(c)$ with total porosity in most giant pumices (Fig. 4c). Banded GP290 fragments have only $0-2 \%$ isolated porosity at $75-82 \%$ total porosity where $c \sim 1$; the GP290 vesicle network is almost fully connected. Sample GP290 also does not show systematic changes in vesicularity

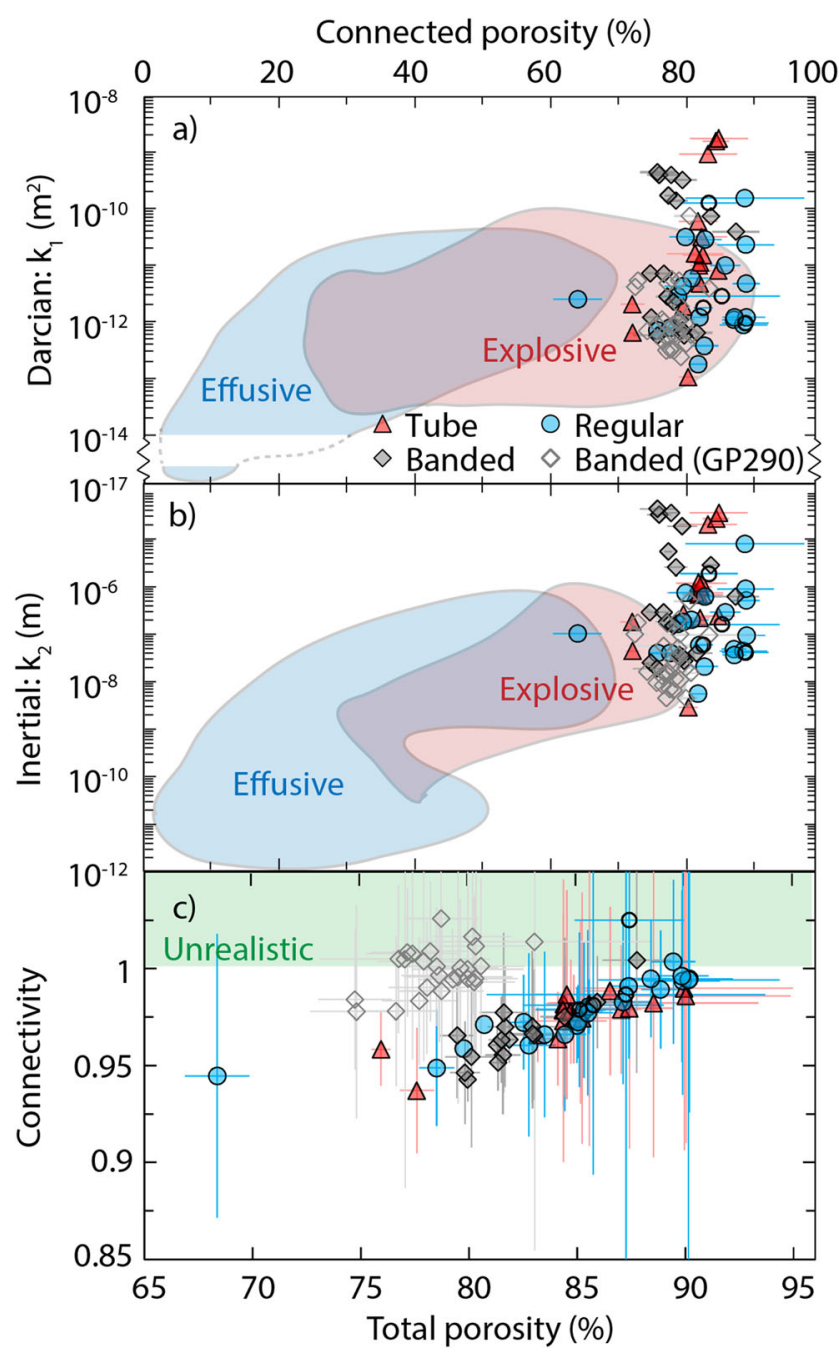

Fig. 4 Permeability versus connected porosity (a) and (b), and total porosity versus connectivity $(\mathbf{c})$. Connected porosity is compared against both the Darcian $\left(k_{1}\right)$ and inertial $\left(k_{2}\right)$ permeability $(\mathbf{a}, \mathbf{b})$. The regions defined by effusive and explosive are determined from multiple datasets of subaerial pumice (Degruyter et al. 2012). Empty symbols (primarily GP290) are data from Manga et al. (2018a). Connectivity values $>1$ are a result of random error; this is shown through the \pm 2 SD error bars. Full data and sample names are given in Online Resource 6

with distance from the outer margin. All other giant pumice exteriors sit on a different trend where there is up to $5 \%$ isolated porosity at a total porosity of $75 \%$. Connectivity only approaches one where total porosity is $>87 \%$ (Fig. 4c). Other finely banded giant pumice exteriors exhibit lower connectivity than the rest of the regular and tube samples, but these samples do not sit on the same trend as GP290 (see Online Resource 8 for the plot of all data). There is no discernable difference between interior and exterior cores from GP290, all display $c$ values $>0.98$ with overlapping error.

\section{Microlite and vesicle microtextures}

Microlites of pyroxene and feldspar are generally 5-20 $\mu \mathrm{m}$ long and consistently smaller than $50 \mu \mathrm{m}$. Habits are mostly 

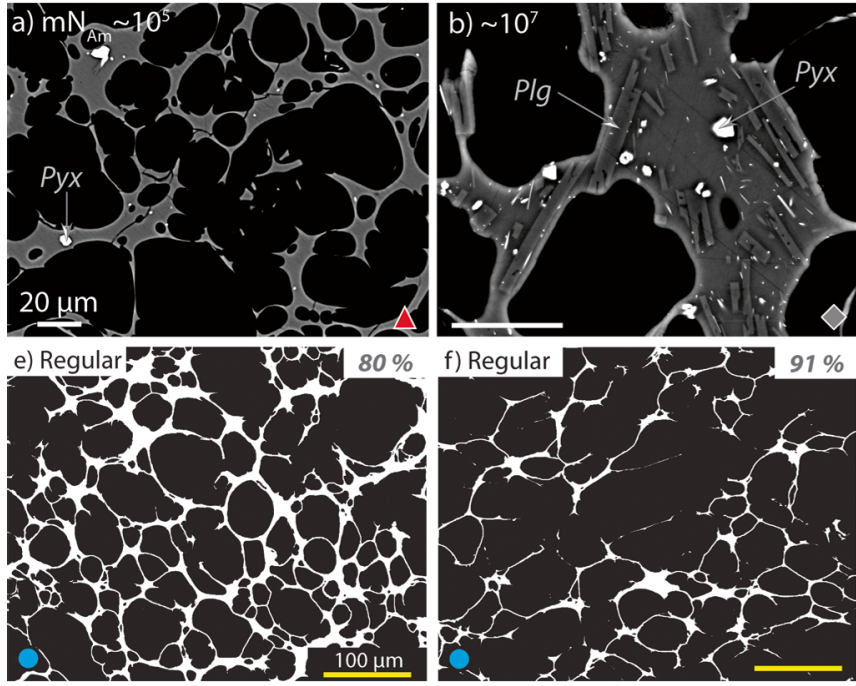

Fig. 5 BSE images of microlite phases, habits, and number densities and vesicles. (a) and (b) identify the crystal phases of pyroxene (Pyx) and plagioclase $(\mathrm{Plg})$ from $10^{5}$ to $10^{7} \mathrm{~cm}^{-2}$; (c) shows the sharp interface (red line) and number density difference between gray (gray diamond) and white bands (white diamond); (d) shows how the growth of plagioclase microlites impedes vesicle edge relaxation (circled in yellow). Each image (a to d) is given a $20-\mu \mathrm{m}$ scale bar and $\mathrm{mN}_{\mathrm{Am}}$ values in (a) and

acicular (pyroxene) and swallow-tail to tabular (feldspar) (Fig. 5). Vesicularity-corrected microlite number density $\left(\mathrm{mN}_{\mathrm{Am}}\right)$ varies over two orders of magnitude; tube and regular giant pumices have $\mathrm{mN}_{\mathrm{Am}}$ values of $2 \times 10^{5}$ to $3 \times 10^{6} \mathrm{~cm}^{-2}$. White and gray pumice bands in GP290 are an order of magnitude higher than regular and tube pumices $\left(8 \times 10^{6}\right.$ to $2 \times 10^{7} \mathrm{~cm}^{-2}$ ) (Fig. 5b). The higher number densities in gray bands are attributed to dominant feldspar nucleation and increases in pyroxene and oxide nucleation; very few feldspar microlites are identified within tube and regular pumices (Fig. 5a) (see Online Resource 9 for all microlite data). There are well-defined, sharp interfaces in $\mathrm{mN}_{\mathrm{Am}}$ between adjacent gray and white bands, where gray bands have up to $10 \times$ more microlites (Fig. 5 c). In banded clasts, the edges of sub-rounded vesicles are commonly aligned to the elongate edges of microlites with acicular-tabular habits (Fig. 5d).

Vesicle sizes, shapes, connectedness, and abundances were examined in both 2D and 3D for GP290, to provide a 3D understanding of the relationship between vesicle shape and connectedness (Figs. 3, 4, and 5). Vesicles analyzed in 2D display a range of shapes and textural maturity (extent of bubble coalescence and deformation) although most giant pumice exteriors are dominated by vesicles $10-100 \mu \mathrm{m}$ in diameter with well-rounded shapes and little evidence of collapsed degassing pathways (Fig. 5e-h). In exteriors of regular pumices, some circular vesicles are observed between vesicles with more convoluted perimeters and irregular shapes (Fig. 6). Banded GP290 exterior and interior samples have similar vesicularities and vesicle sizes to regular pumices, but the vesicle shapes conform to the shapes of adjacent microlites (Fig. 5h).

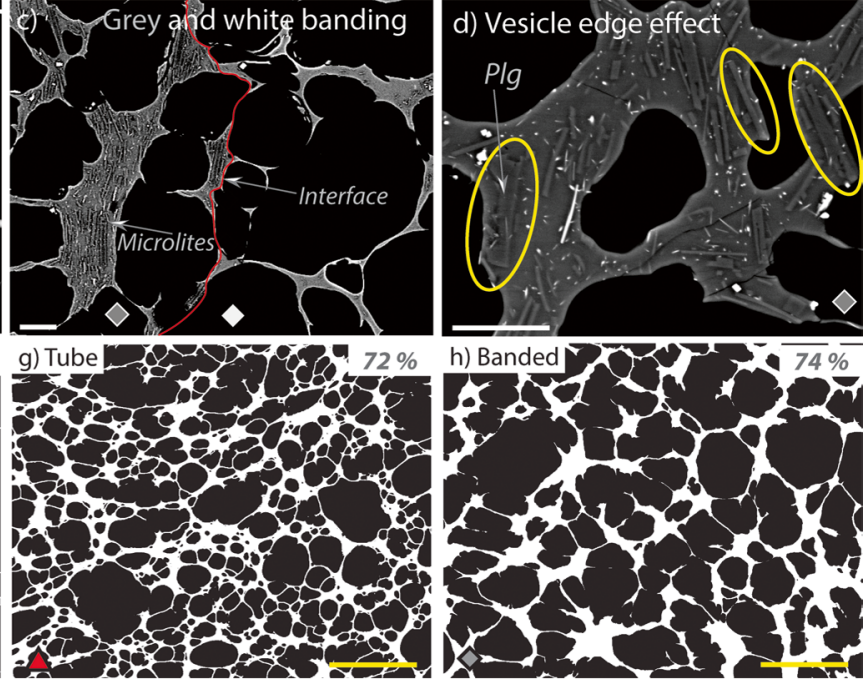

(b) are in $\mathrm{cm}^{-2}$. Processed binary BSE images (e) through (h) are acquired at $\times 250$ magnification. Black is vesicle pore space and white is glass, phenocrysts and microlites. Each image gives the textural classification, the $2 \mathrm{D}$ image vesicularity $(\%)$ and a $100-\mu \mathrm{m}$ scale bar. All images are given prior to separation of coalesced vesicles. Tube vesicles (g) are viewed as a normal cut of the elongate vesicle axis (i.e., shortest diameter)

Cross sections of vesicles in tube samples are nearly circular when not affected by coalescence (Fig. $5 \mathrm{~g}$ ).

\section{Vesicle number densities $\left(\mathrm{N}_{\mathrm{Vm}}\right)$}

Vesicle number densities for all giant pumice clast exteriors examined with 2D image analysis span almost an order of magnitude $\left(2.6 \times 10^{8}\right.$ to $\left.1.3 \times 10^{9} \mathrm{~cm}^{-3}\right)$ when assuming spherical vesicle geometry following Sahagian and Proussevitch (1998) (Fig. 7a). Tube pumice exteriors have consistently higher apparent $\mathrm{N}_{\mathrm{Vm}}$ values $\left(1.1 \times 10^{9} \mathrm{~cm}^{-3}\right.$ to $1.3 \times 10^{9} \mathrm{~cm}^{-3}$ ), but the extreme elongation of vesicles in tube pumices means that the assumption of sphericity is not valid, and their actual $\mathrm{N}_{\mathrm{Vm}}$ is lower. Here, we apply an alternative formula for stereo-conversion assuming a prolate, rather than spherical, vesicle geometry (as used by Sahagian and Proussevitch (1998)), of 1:3:10, where one and three are the measured vesicle diameters and 10 is the prolate axis (see Appendix 1 for full stereo-conversion details). The range of aspect ratios was determined by XRT analysis for pumice cores. Of the conversion factors in Sahagian and Proussevitch (1998), the non-spherical assumption of 1:3:10 is the best available approximation for our tube samples where the majority of vesicle sizes in question $(10-100 \mu \mathrm{m})$ have aspect ratios of 10-50 (see Online Resource 5).

By applying the tube-vesicle stereo-conversion, number densities of tube pumice exteriors are reduced (1.9$2.6 \times 10^{8} \mathrm{~cm}^{-3}$ ) and closely match the GP290 exterior banded values of 2.5-3.6 $\times 10^{8} \mathrm{~cm}^{-3}$. An interior fragment of GP290 with $80 \%$ vesicularity has similar $\mathrm{N}_{\mathrm{Vm}}\left(3.1 \times 10^{8} \mathrm{~cm}^{-3}\right)$ to the 

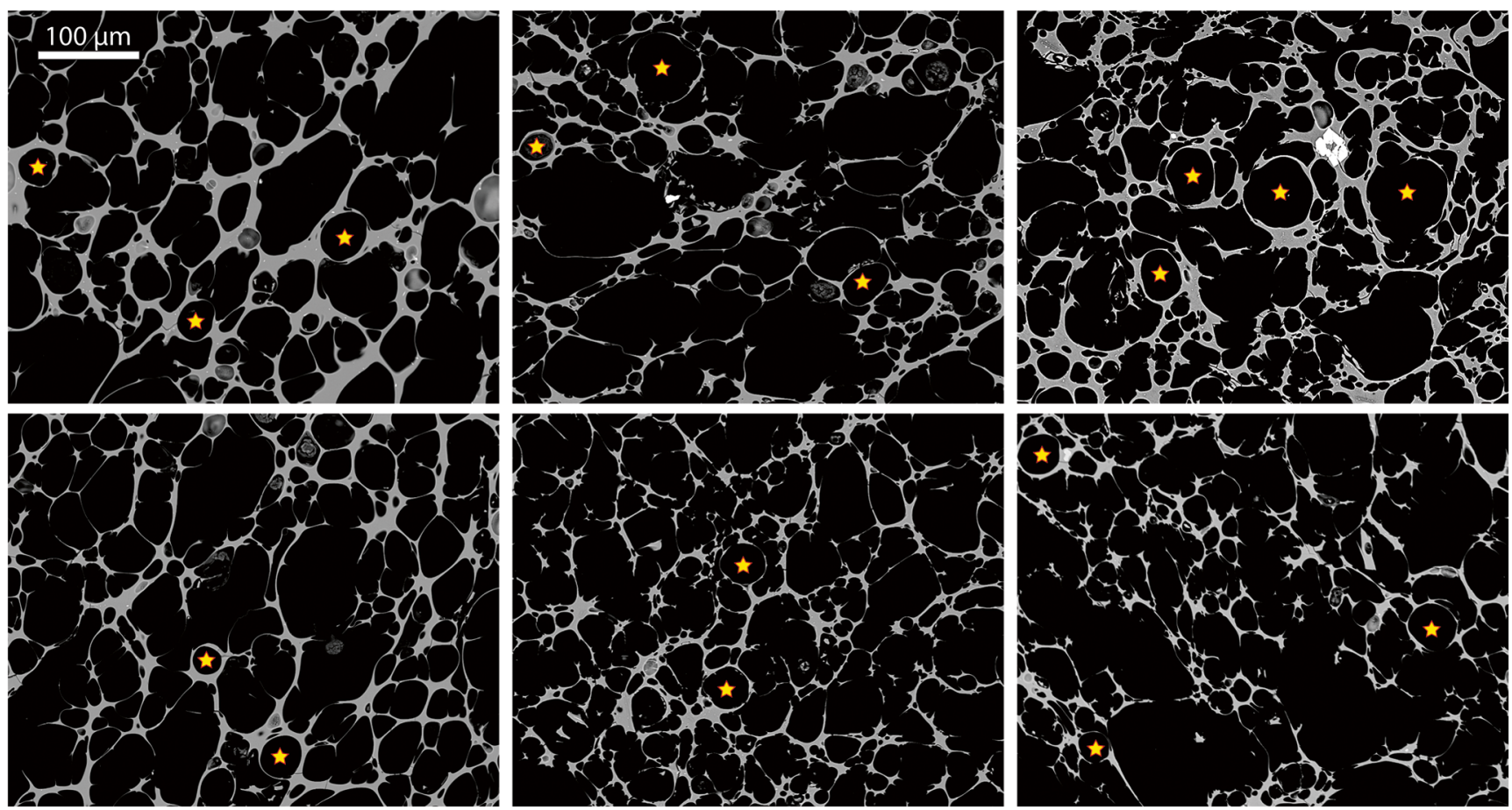

Fig. 6 BSE images at $\times 250$ magnification of vesicles with implied secondary growth. Each image is $480 \mu \mathrm{m}$ in diameter. Vesicles with deformed shapes surround very circular vesicles. Stars denote some of vesicles with inferred secondary growth

GP290 exteriors. Some stretched bubbles in regular giant pumice exteriors necessitate the use of a smaller aspect ratio geometry (1:1:2) (Fig. 7). With a 1:1:2 correction, regular pumice $\mathrm{N}_{\mathrm{Vm}}$ values are reduced from $5.9-7.8 \times 10^{8} \mathrm{~cm}^{-3}$ to $4.6-6.0 \times 10^{8} \mathrm{~cm}^{-3}$. With or without correction, regular pumice exteriors have higher $\mathrm{N}_{\mathrm{Vm}}$ values than GP290 exteriors where smaller vesicles $(<20 \mu \mathrm{m})$ are sparse (Figs. $5 \mathrm{~h}$ and 7 ) and there is negligible isolated porosity (Fig. 4c). Correcting for elongate vesicles narrows the total range of vesicle number densities identified in all giant pumice exteriors (1.9$6.0 \times 10^{8} \mathrm{~cm}^{-3}$ ). We expect some natural variation in $\mathrm{N}_{\mathrm{Vm}}$ in a single magma source, but generally, $\mathrm{N}_{\mathrm{Vm}}$ from GP are very consistent in comparison to subaerial systems (Houghton et al. 2010; Shea et al. 2010). These values are lower than those obtained for three raft pumices from Havre 2012 (6.6$12.1 \times 10^{8} \mathrm{~cm}^{-3}$ ) as analyzed by Rotella et al. (2015).

\section{Vesicle volume distributions (VVDs)}

The modal vesicle diameter by volume is relatively consistent through all clast exteriors $(30-48 \mu \mathrm{m})$ with the exception of regular pumice sample HVR_192 (60 $\mu \mathrm{m})$ (Fig. 8, Table 2). The modal vesicle diameter by number density is similar (16$37 \mu \mathrm{m}$ ) showing that total porosity is dominated by the most numerous vesicle size. Vesicle volume distributions cannot be accurately determined for tube pumices after the extreme stereo-conversion; the calculations are only valid for a spherical assumption (see Appendix 1 and Online Resource 4). Comparison of adjacent white and gray bands show an increase in small, circular vesicles $(<60 \mu \mathrm{m})$ in white bands (Fig. 81). Some regular pumices display subtle bimodal distributions with a consistent primary mode at 30-60 $\mu \mathrm{m}$ and a variable secondary mode at 100-600 $\mu \mathrm{m}$ (Fig. 8a-e). Table 2 compiles all 2D microtextural data for each giant pumice exterior.

\section{Magma decompression rates and post-fragmentation bubble expansion}

Similar vesicle number densities among GP clasts imply a common early ascent history of GP magma where $\mathrm{N}_{\mathrm{Vm}}$ values of $10^{8} \mathrm{~cm}^{-3}$ are associated with dominantly heterogeneous bubble nucleation at crystals edges or at melt impurities (Shea 2017). Despite the low crystallinity of Havre giant pumices ( $\sim 5$ vol.\%; Carey et al. 2018), bubble growth at free crystal surfaces produces vesicles $100-200 \mu \mathrm{m}$ in diameter; these contribute towards the coarser mode in the VVDs (Fig. 8). Silicic Plinian eruptions commonly produce pumice with $\mathrm{N}_{\mathrm{Vm}}$ of $10^{9}-10^{10} \mathrm{~cm}^{-3}$ (e.g., Novarupta, Vesuvius, Askja, Taupo, Mt. St. Helens; Adams et al. 2006; Carey et al. 2009; Gurioli et al. 2005; Houghton et al. 2010). The highest values are attributed to late-stage, very high decompression rates $\left(d P / d t \sim 10-100 \mathrm{MPa} \mathrm{s}^{-1}\right)$ and non-linear, rapid vesicle nucleation in the very shallow conduit $(<10 \mathrm{MPa})$ prior to fragmentation (Cluzel et al. 2008; Shea 2017; Toramaru 2006). For the GP phase of the 2012 Havre eruption, we calculate maximum $d P / d t$ of $0.9-5.0 \mathrm{MPa} \mathrm{s}^{-1}$ at the 


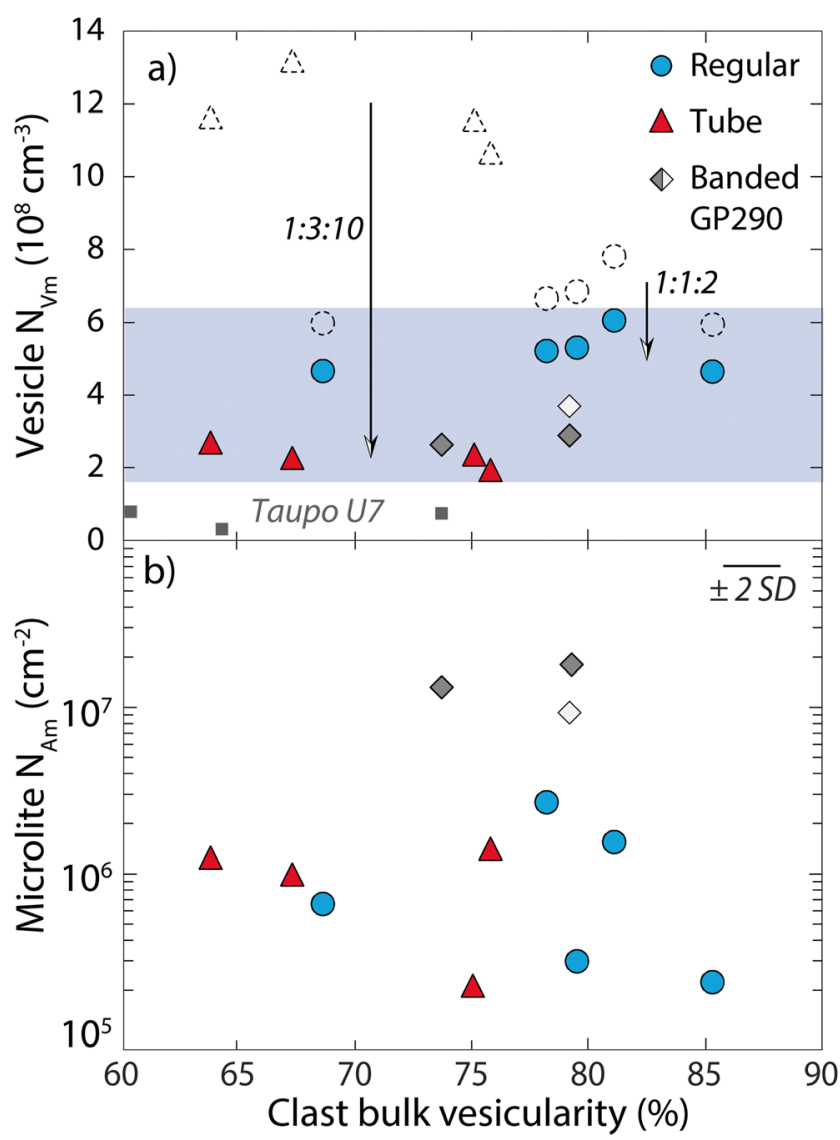

Fig. 7 a Corrected vesicle number density per volume $\left(\mathrm{N}_{\mathrm{Vm}}\right)$ versus clast vesicularity for all analyzed samples when applying a non-spherical 3D stereo-conversion for defined aspect ratios appropriate to the whole-clast macrotextural and $3 \mathrm{D}-\mu \mathrm{XRT}$ microtextural observations. Banded pumice does not require a non-spherical assumption. The blue box highlights the resulting small range of $\mathrm{N}_{\mathrm{Vm}}$ values from the adjustment. Number densities are also given for the $1.8 \mathrm{ka}$ Taupo Unit 7 giant pumiceous blocks from Houghton et al. (2010) (gray squares). b Melt-corrected microlite number density per area $\left(\mathrm{mN}_{\mathrm{Am}}\right)$ vs clast vesicularity for all analyzed samples. Vesicularity error given by $\pm 2 \mathrm{SD}$ (black line)

vent using our corrected $\mathrm{N}_{\mathrm{Vm}}$ range (Fig. 7) and the Shea (2017) $d P / d t$ equation for a rhyolite. These decompression rates are insufficient to produce rapid vesicle nucleation (Gonnermann and Manga 2005a; Toramaru 2006). The termination of the Havre conduit at 9.2 MPa prevents processes such as late-stage vesicle nucleation, disequilibrium degassing and explosive magma fragmentation (Manga et al. 2018a).

Tube and regular giant pumices have total microlite number densities of $10^{4}-10^{6} \mathrm{~cm}^{-2}$ (Fig. $7 \mathrm{~b}$ ), but plagioclase microlite number densities of only $10^{3}-10^{4} \mathrm{~cm}^{-2}$. These latter values do not correspond to $d P / d t$ of $0.9-5.0 \mathrm{MPa} \mathrm{s}^{-1}$, and are thus indicative of non-decompressive microlite growth (Toramaru et al. 2008). However, GP290 with plagioclase microlite number densities of $10^{6}-10^{7} \mathrm{~cm}^{-2}$ corresponds to $d P / d t$ of $<0.002 \mathrm{MPa} \mathrm{s}^{-1}$ suggesting late-stage plagioclase crystallization driven by decompression rather than cooling (Blundy and Cashman 2008; Brugger and Hammer 2010a;
Toramaru et al. 2008). We can exclude rapid microlite nucleation as a result of undercooling as vesicle number densities are too low (Toramaru 2014). This implies that extended microlite nucleation and growth seen in GP290 was by produced at $d P / d t$ of $<<0.01 \mathrm{MPa} \mathrm{s}^{-1}$ (similar to vesicle-poor rhyolite lava effusion; Brugger and Hammer 2010b) in a localized region of the conduit. Instead, smaller numbers of plagioclase microlites in tube and regular pumice grew sporadically during cooling upon settling and deposition.

Subtle bimodal VVDs with varying coarse modal size and volume demonstrate that there were variable vesiculation controls after an early common ascent despite similar $\mathrm{N}_{\mathrm{Vm}}$. Bimodal VVD signatures are observed in many subaerial rhyolite pumice eruptions, but these coarser modes are usually broader and attributed to bubble coalescence (Carey et al. 2009; Giachetti et al. 2010; Houghton et al. 2010; Janebo et al. 2016; Schipper et al. 2010a; Shea et al. 2010). We observe coalesced vesicles in giant pumice exteriors. However, these vesicles could be sufficiently separated to reconstruct more accurate pre-eruptive VVDs (Fig. 5, Online Resource 4). The coarser modes $(100-600 \mu \mathrm{m})$ vary in volume and modal size more than the primary vesicle modes at 30 $60 \mu \mathrm{m}$ and display highly heterogeneous textures. We attribute these to a variable extent of heterogeneous bubble growth around crystals, and some post-disruption vesicle expansion.

Some regular giant pumice exteriors appear to show the expansion of bubbles post-disruption and fragmentation, i.e., post-eruptive bubble growth through disequilibrium volatile exsolution (e.g., Gonnermann and Manga 2005a; Klug et al. 2002; Mitchell et al. 2018b). This is implied from some breadcrusted exteriors, and is evident from the presence of coexpanded vesicles where smaller bubbles had higher internal pressure and, hence, deformed adjacent larger bubbles (Figs. $1 \mathrm{~h}$ and 6). The subsequent deformed vesicles have flattened or concave edges to accommodate the late-stage growth of the adjacent near-spherical bubble (Fig. 6; Klug et al. 2002). The difference in adjacent vesicle shapes and sizes suggests two distinct stages of vesicle growth and magma decompression (Klug et al. 2002). These deformed vesicles do not share the expected vesicle convolution and breakdown textures seen as "collapsing" vesicles (Rust and Cashman 2004).

Post-eruptive vesicle growth is not widely recorded in subaerial rhyolite due to an ambient environment that limits postdisruption decompressive expansion (Thomas et al. 1994; Houghton et al. 2010). Tropospheric $d P / d t$ are $\sim 10^{-5}$ $10^{-4} \mathrm{MPa} \mathrm{s}^{-1}$ whereas submarine $d P / d t$ are $\sim 0.01-$ $0.1 \mathrm{MPa} \mathrm{s}^{-1}$ for pyroclasts ascending at 1 to $10 \mathrm{~m} \mathrm{~s}^{-1}$ (these being the exit velocities for the Havre eruption as calculated by Manga et al. $(2018 \mathrm{a}, \mathrm{b}))$. Greater $d P / d t$ and vapor trapping (Fauria et al. 2017) during submarine clast ascent would allow continued expansion of bubbles. Values of $d P / d t$ in this range, however, are insufficient for late-stage nucleation in the water 


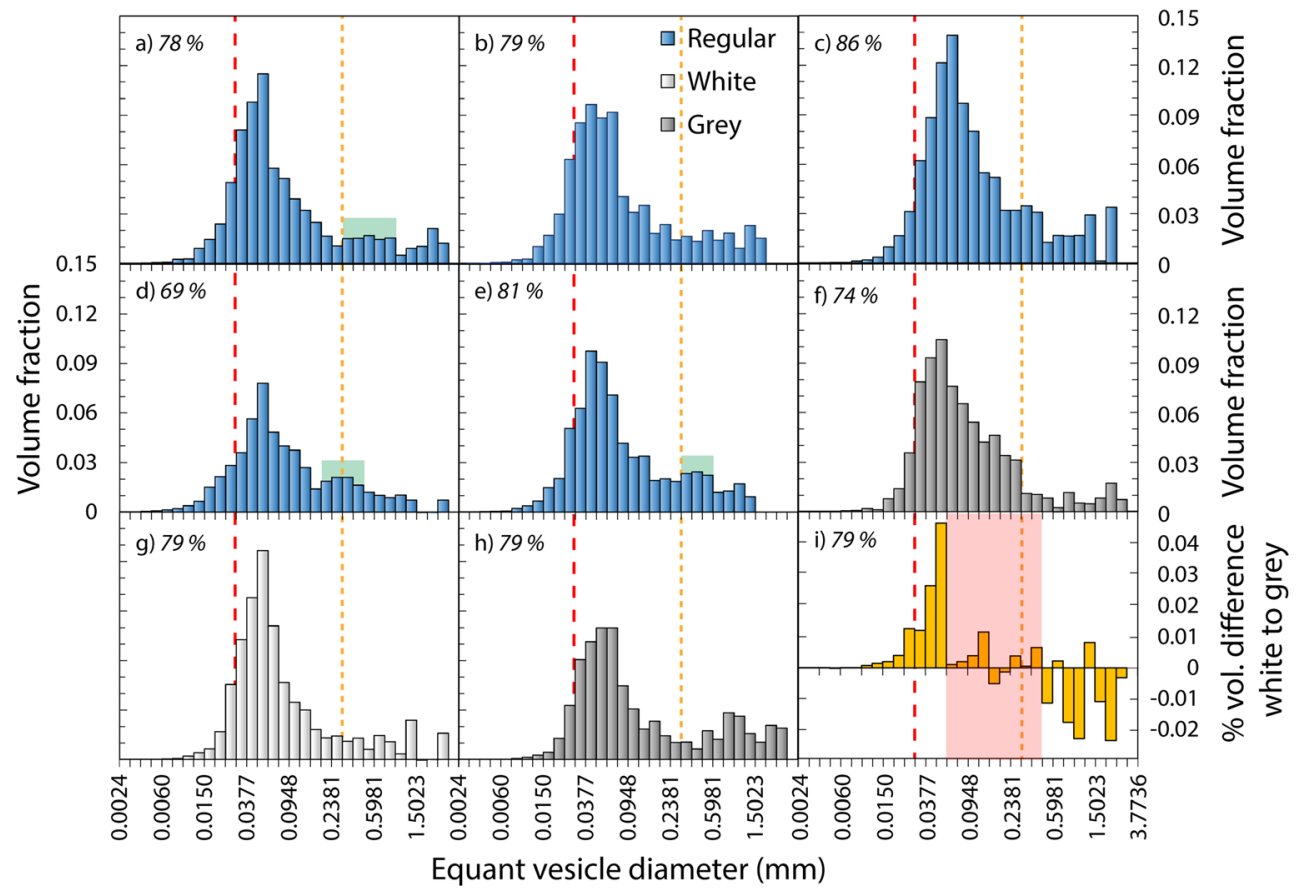

Fig. 8 Vesicle volume distributions (VVDs) for all samples except for tube pumices (see Appendix 1). Equant vesicle diameters are given across 32 geometric bins $\left(\times 10^{0.1}\right.$ from Sahagian and Proussevitch (1998)) from $2.4 \mu \mathrm{m}$ to $3.78 \mathrm{~mm}$. Absolute volume fractions are given as opposed to fractions adjusted to $100 \%$ volume. Whole clast vesicularity is given for all samples. The red dashed and yellow dotted lines correspond to reference vesicle sizes of $30 \mu \mathrm{m}$ and $300 \mu \mathrm{m}$, respectively to compare volume contributions of the smallest, modal and largest vesicle diameters. Plot (i) displays the \% volume difference between the \%-adjusted VVDs of (g) and (h) - adjacent white and gray bands in GP290. The red box shows a region of inconsistent variation in volume in (i). Coarser modes qualitatively identified by pale green box

Table 2 Vesicle and microlite parameters and outputs from 2D image analysis and 3D stereo-conversions

\begin{tabular}{|c|c|c|c|c|c|c|c|c|c|c|c|c|c|}
\hline Group & $\begin{array}{l}\text { Sample } \\
\#: H V R \_\end{array}$ & $\begin{array}{l}\text { Vent } \\
\text { distance } \\
(\mathrm{km})\end{array}$ & $\begin{array}{l}\text { Fragment } \\
\text { vesic.* } \\
(\%)\end{array}$ & $\begin{array}{l}\text { Mean } \\
\text { image } \\
\text { vesic. } \\
(\%)\end{array}$ & $\begin{array}{l}\text { Clast } \\
\mathrm{V}_{\mathrm{g}} / \mathrm{V}_{1}\end{array}$ & $\begin{array}{l}\text { Vesicles } \\
\text { analyzed }\end{array}$ & $\begin{array}{l}\text { Vesicles } \\
\text { included }\end{array}$ & $\begin{array}{l}\mathrm{N}_{\mathrm{V}} \\
\left(\mathrm{cm}^{-3}\right)\end{array}$ & $\begin{array}{l}\mathrm{N}_{\mathrm{Vm}} \\
\left(\mathrm{cm}^{-3}\right)\end{array}$ & $\begin{array}{l}\text { Adjusted } \\
\mathrm{N}_{\mathrm{Vm}} * * \\
\left(\mathrm{~cm}^{-3}\right)\end{array}$ & $\begin{array}{l}\mathrm{mN}_{\mathrm{Am}} \\
\left(\mathrm{cm}^{-2}\right)\end{array}$ & $\begin{array}{l}\text { Modal } \\
3 \mathrm{D} \\
\text { EqD*** } \\
(\mu \mathrm{m})\end{array}$ & $\begin{array}{l}\text { Modal } \\
\text { volume } \\
\mathrm{EqD}^{+} \\
(\mu \mathrm{m})\end{array}$ \\
\hline \multirow[t]{5}{*}{ Regular } & 041 & 3.12 & 78.1 & 66.9 & 3.57 & 14,966 & 3622 & $6.3 \times 10^{7}$ & $6.6 \times 10^{8}$ & $5.1 \times 10^{8}$ & $2.7 \times 10^{6}$ & 25.7 & 47.5 \\
\hline & 096 & 1.65 & 79.4 & 73.1 & 3.85 & 13,780 & 3080 & $6.0 \times 10^{7}$ & $6.8 \times 10^{8}$ & $5.3 \times 10^{8}$ & $3.3 \times 10^{5}$ & 25.7 & 37.7 \\
\hline & 192 & 1.19 & 85.2 & 82.5 & 5.76 & 9873 & 1916 & $3.7 \times 10^{7}$ & $6.0 \times 10^{8}$ & $4.6 \times 10^{8}$ & $2.6 \times 10^{5}$ & 32.4 & 59.8 \\
\hline & 221 & 4.65 & 68.5 & 60.8 & 2.17 & 16,769 & 3835 & $7.9 \times 10^{7}$ & $5.9 \times 10^{8}$ & $4.6 \times 10^{8}$ & $7.0 \times 10^{5}$ & 32.4 & 47.5 \\
\hline & 231 & 5.81 & 81.0 & 69.3 & 4.26 & 11,038 & 3390 & $6.0 \times 10^{7}$ & $7.8 \times 10^{8}$ & $6.0 \times 10^{8}$ & $1.6 \times 10^{6}$ & 16.2 & 37.7 \\
\hline \multirow[t]{4}{*}{ Tube } & 003 & 1.03 & 75.0 & 74.2 & 3.00 & 14,275 & 4676 & $5.7 \times 10^{7}$ & $1.2 \times 10^{9}$ & $2.3 \times 10^{8}$ & $2.3 \times 10^{5}$ & 37.1 & 47.5 \\
\hline & 022 & 1.20 & 63.7 & 61.0 & 1.75 & 25,356 & 6447 & $9.5 \times 10^{7}$ & $1.2 \times 10^{9}$ & $2.6 \times 10^{8}$ & $1.3 \times 10^{6}$ & 37.1 & 30.0 \\
\hline & 115 & 0.42 & 75.7 & 75.7 & 3.12 & 18,088 & 3935 & $4.5 \times 10^{7}$ & $1.1 \times 10^{9}$ & $1.9 \times 10^{8}$ & $1.5 \times 10^{6}$ & 29.5 & 47.5 \\
\hline & 270 & 4.92 & 67.2 & 67.4 & 2.05 & 14,882 & 5244 & $7.3 \times 10^{7}$ & $1.3 \times 10^{9}$ & $2.2 \times 10^{8}$ & $1.0 \times 10^{6}$ & 29.5 & 30.0 \\
\hline \multirow[t]{4}{*}{ Banded } & 290 & 1.43 & 73.6 & 65.7 & 2.79 & 9542 & 3119 & $6.7 \times 10^{7}$ & $2.6 \times 10^{8}$ & $\mathrm{n} / \mathrm{a}$ & $1.3 \times 10^{7}$ & 30.0 & 47.5 \\
\hline & 290_G & 1.43 & 79.1 & 68.9 & 3.78 & 11,078 & 1936 & $5.9 \times 10^{7}$ & $2.8 \times 10^{8}$ & $\mathrm{n} / \mathrm{a}$ & $1.8 \times 10^{7}$ & 23.8 & 47.5 \\
\hline & 290_W & 1.43 & 79.1 & 76.1 & 3.78 & 16,564 & 2323 & $7.5 \times 10^{7}$ & $3.6 \times 10^{8}$ & $\mathrm{n} / \mathrm{a}$ & $9.3 \times 10^{6}$ & 23.8 & 59.8 \\
\hline & 290 (int) & 1.43 & 79.3 & 70.4 & 3.83 & 9435 & 2775 & $6.4 \times 10^{7}$ & $3.1 \times 10^{8}$ & $\mathrm{n} / \mathrm{a}$ & $4.8 \times 10^{6}$ & 23.8 & 37.7 \\
\hline
\end{tabular}

* Selected fragment vesicularity (vesic.) is equal to the mean giant pumice vesicularity from each density distribution analysis (see supplement 1 )

**Bubble number density $\left(\mathrm{N}_{\mathrm{Vm}}\right)$ adjusted with the most appropriate non-spherical vesicle geometry stereo-conversion

***Modal vesicle diameter from number density per size bin after 3D stereo-conversion. Value take from size bin median

${ }^{+}$Modal vesicle diameter by total vesicle volume, i.e., histogram mode from Fig. 8. Note that tube values may be inaccurate due to non-prolate stereoconversion included here 
column. This likely explains the greater measured vesicularities (up to $92 \%$ ) relative to those predicted at seafloor vent pressures by Manga et al. (2018a) (i.e., 75-80\%). The irregular, convex shape of surrounding vesicles also suggests that post-eruptive bubble growth occurs while magma is still ductile and bubbles can still deform. Many of these post-eruptive vesicles appear isolated in the 2D images; isolated bubbles would permit expansion of vapor within the bubble without outgassing (Fig. 6). Up to 5\% isolated porosity would still permit post-eruptive bubble growth and increased vesicularity, despite the high vesicle connectivity (Fig. 4c). Late-stage bubble expansion supports previous hypotheses that giant pumices cool slowly in the water column (Fauria and Manga 2018; Mitchell et al. 2018a). In this regard, we note that residence time of giant pumices within a possible thermal plume before settling in cold seawater will be a dominant control on clast cooling rates (Mitchell et al. 2018a).

\section{Discussion}

Geochemical homogeneity throughout the Havre GP unit suggests that observed textural diversity arises from a combination of physical processes above and below the vent. The following discussion develops a 2D strain model and a conceptual shallow conduit model to explain the observed textures. We then explore processes that accompany ascent of hot giant pumice blocks within the water column, and the underlying controls on production of giant pumice in the submarine environment.

\section{Eruptive shallow conduit model}

We propose that (1) a velocity gradient across the conduit (as proposed by Polacci et al. 2001; Shea et al. 2012; Shea et al. 2014; Wright et al. 2006) created spatially variable shear that is reflected in the textural differences between regular and tube pumices; and (2) that cooling and/or further degassing near the conduit walls produces magma with lower ascent velocity that permits microlite growth and subsequent banding.

\section{Strain and bubble deformation}

We use a 2D axisymmetric conduit strain model to assess how textures observed in both tube and regular giant pumices could be produced simultaneously, prior to eruption into the water column. The results of the $1 \mathrm{D}$ conduit ascent model by Manga et al. (2018a) (as initialized and described in online resource 10 and Appendix 2) provide input parameters for the 2D model as applied here, which terminates at $9 \mathrm{MPa}$ (hydrostatic- equivalent vent depth), and assumes constant conduit radii (25 and $50 \mathrm{~m}$ ) and a laminar velocity profile (as also assumed in the $1 \mathrm{D}$ model).

We calculate cumulative strain $\left(\gamma_{t}\right)$, expected maximum bubble aspect ratios (AR), and decompression rates $(d P / d t)$ throughout the conduit, focusing on the results from the shallow conduit ( $200 \mathrm{~m}$ below the vent; Manga et al. 2018a). Cumulative strain calculations only initiate when the capillary number $(\mathrm{Ca})$ is $>1$ in the conduit, i.e., when the timescale of bubble relaxation exceeds the timescale of bubble shearing. Below this, vesicle deformation will be negligible. We use equations from Canedo et al. (1993) and Rust and Manga (2002) for $\mathrm{Ca}$ and AR calculations. In this instance, vesicles - and subsequent AR calculations - are assumed to undergo simple shear due to the velocity profile as opposed to pure shear prior to conduit fragmentation (Dingwell et al. 2016). Details of the model are explained in Appendix 2.

A 25-m radius conduit leads to significant cumulative strain $\left(\gamma_{t}>>10\right)$ in the shallow conduit (Fig. 9). For this scenario, $\gamma_{\mathrm{t}}$ approaches $10^{4}$ at the conduit walls, but strain rates remain insufficient to fragment magma in the conduit, even at the walls. Decompression rates vary from 5 to $0.1 \mathrm{MPa} \mathrm{s}^{-1}$ with distance from the conduit centermatching those predicted by Shea (2017) — and modal vesicle size AR are $>>10$ throughout the shallow conduit (Fig. 9b). There is only a very narrow region $(<1.5 \mathrm{~m}$ across $)$ in the conduit where $\mathrm{Ca}<1$ and little strain accumulates. A conduit with a $25-\mathrm{m}$ radius would not be able to produce the nonsheared vesicle textures observed in regular and banded giant pumices. Instead, textures would be dominated by elongate tube vesicles (Dingwell et al. 2016).

If we increase the conduit radius to $50 \mathrm{~m}$ and maintain mass eruption rate (MER) by reducing velocity, we can explore the lower strain conditions required to produce $\mathrm{m}$-scale regions with very little vesicle shear, as in regular giant pumices. For this model, most of the conduit experiences low strain rates $(\mathrm{Ca}<1)$ until the final $1000 \mathrm{~m}$, where total strain at the vent is significantly lower than the $25 \mathrm{~m}$ case (Fig. 9). The conduit edges still experience high strain $\left(\gamma_{\mathrm{t}}>100\right)$, but there is a 20 $\mathrm{m}$ wide region in the center of the shallow conduit where $\gamma_{\mathrm{t}}<$ 1. Lower velocities also result in lower $d P / d t$ of 0.7 to $0.01 \mathrm{MPa} \mathrm{s}^{-1}$. The $\mathrm{Ca}<1$ region in the shallow conduit is larger (i.e., up to $10 \mathrm{~m}$ across) than in the $25 \mathrm{~m}$ model, and would allow for the production of both sheared and nonsheared vesicles at the vent (Fig. 10a).

Manga et al. (2018a) inferred a conduit radius of $21 \mathrm{~m}$ to match the MER determined by Carey et al. (2018). We suggest that a flared shallow conduit radius from 25 to $50 \mathrm{~m}$ (or greater) in the final $200 \mathrm{~m}$ of magma ascent would be sufficient to generate shallow regions with low accumulated strain and 


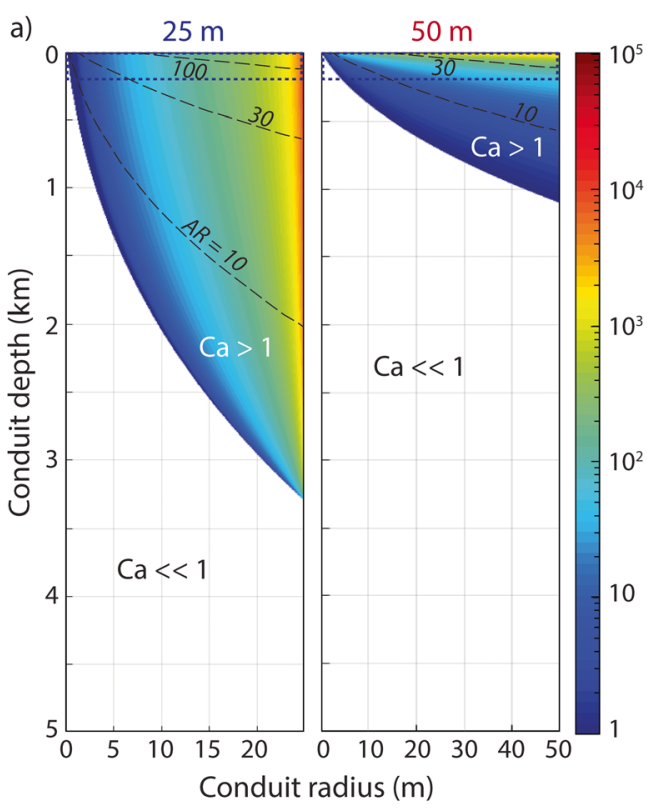

Fig. 9 2D strain modeling of the two conduit radii $(25$ and $50 \mathrm{~m})$ assuming constant mass eruption rate $\left(10^{7} \mathrm{~kg} \mathrm{~s}^{-1}\right.$ from Carey et al. (2018). Conduit center $=0 \mathrm{~m}$, conduit wall $=25$, or $50 \mathrm{~m}$ (as in c)). The model shows the cumulative conduit strain $\left(\gamma_{\mathrm{t}}\right)$ when $\mathrm{Ca}>1$ in both conduits, with expected vesicle aspect ratios (AR) given by dashed

spherical vesicles. Mechanical erosion near the surface (seafloor) can widen conduits to create a flared vent, with models predicting widening by a factor of up to two or three (Aravena et al. 2018). If GP was produced at lower MER than the pumice raft (i.e., $<<10^{7} \mathrm{~kg} \mathrm{~s}^{-1}$ ), then it is also possible to generate the required conditions in a narrower conduit. Either
$25 \mathrm{~m}$

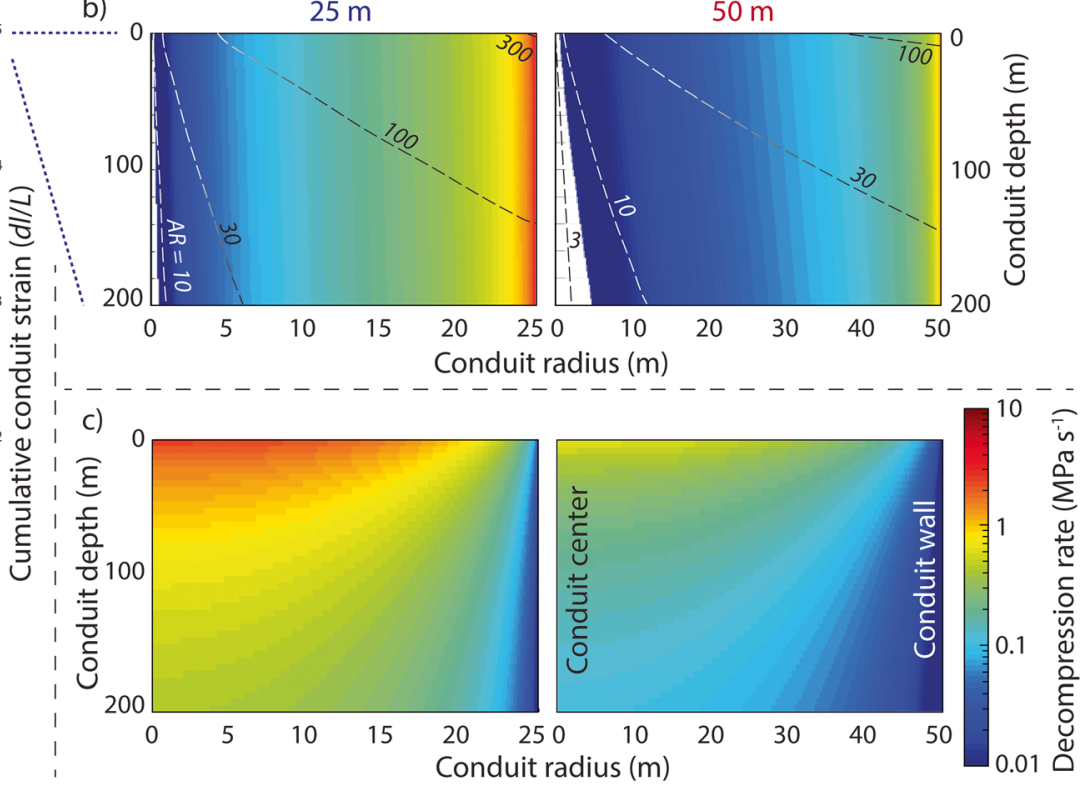

lines. Plots with the same strain color bar for a $5 \mathrm{~km}$ of the conduit and b the top $200 \mathrm{~m}$ of the conduit. Conduit depth of $0 \mathrm{~m}=10 \mathrm{MPa}$. (c) shows the difference in decompression rates $(d P / d t)$ across the same region of the shallow conduit

way, the model suggests that elongate vesicles are likely to be dominant within giant pumice clasts, even when the conduit is flared, although tube vesicles may only be present at very high aspect ratios, i.e., $\mathrm{AR}>>10$. The higher $d P / d t$ in the conduit center (Fig. 9c) may be partially responsible for the higher $\mathrm{N}_{\mathrm{Vm}}$ values in regular giant pumices (Fig. 7). By fixing the

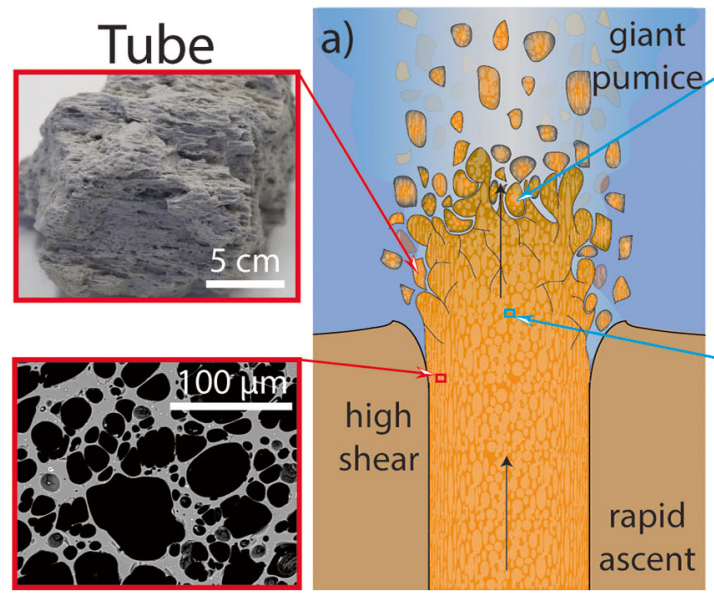

Fig. 10 Schematic model of shallow conduit dynamics leading to the macro- and microtextures observed in a synchronous production of tube and regular giant pumices, and $\mathbf{b}$ later banded giant pumice production from cooling conduit wall and subsequent microlite-rich magma assimilation in the latter stages of the GP phase. The gradient of orange to gray gives an arbitrary temperature scale from fresh magma at $800^{\circ} \mathrm{C}$

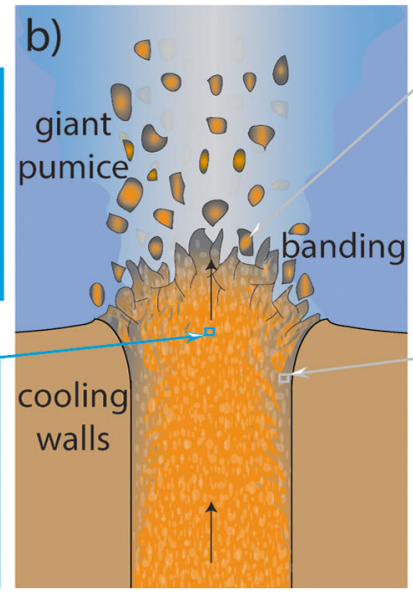

Banded

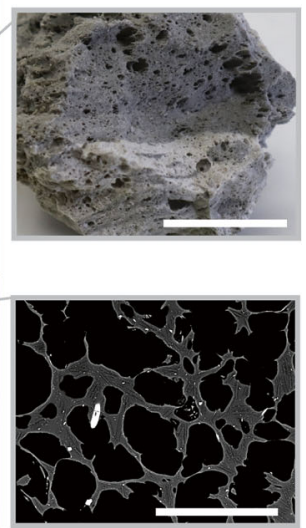

to ambient rock temperature in the ocean. The conduit width, size of eruptive products, and vesicle sizes are not to scale. All images have a 5 -cm scale bar in macrotextures and $100 \mu \mathrm{m}$ in BSE images. Shorter arrows in (b) suggest possible slower ascent rates because of outgassing from the conduit 
vent pressure at $9 \mathrm{MPa}$, we also limit the possibility that gas addition above the vent may reduce apparent hydrostatic pressure and drive higher $d P / d t$ (Mitchell et al. 2018a).

Our sampling of only 29 giant pumice exteriors means we are unable to rigorously confirm that there are more tube giant pumices than regular giant pumices. We also cannot demonstrate the textural diversity throughout all of the pumice suite as only GP290 was collected and analyzed as a whole block. However, there is observable mm-scale textural heterogeneity in most pumices seen as either thin, sinuous denser bands (see Online Resource 7), small regions of shear, or areas with spatially variable vesicle size distributions. Complex conduit geometry or strain localization may generate local textural heterogeneity (Shea et al. 2014; Wright and Weinberg 2009), for example, cm-scale regions of sheared and non-sheared vesicles from some mingling during ascent. This may produce textures like those observed in GP290 (Fig. 3h-k). The lowdensity rind observed in the GP290 CT scan does not appear to be the result of increased vesicularity, a difference in vesicle number density or size distribution, but instead may be the result of more rapid, and a greater extent of, rehydration of the giant pumice exterior. This would support the geochemical evidence for rehydration presented by Mitchell et al. (2018a).

\section{Source of textural banding in GP290}

Macroscopic gray bands in GP290 have higher microlite number densities, and increased microlite size with respect to adjacent white bands and other pumices (Figs. 5 and 7). Sample GP290 also has complete connectivity at lower porosity than other giant pumice samples (Fig. 4c). The juxtaposition of mm to $\mathrm{cm}$-size bands in pumices with distinctly different cooling and crystallization histories suggests mingling of different magma regions with variable cooling rates (Fig. 10b). This has implications for our use of an isothermal conduit model when considering temperature controls on viscosity and consequent strain accumulation.

We propose that the microlite-rich regions are derived from cooler magma at the conduit edges and/or localized shear zones where $d P / d t$ is $<0.1 \mathrm{MPa} \mathrm{s}^{-1}$, and degassing is variable (Fig. 10b; Sano and Toramaru 2017). The complete connectivity of GP290 relative to all other giant pumices in Fig. 4 suggests greater textural maturity, i.e., continued bubble coalescence, and thus, a lack of any isolated vesicles. We infer that permeable, lateral outgassing and a breakdown of coupled gas and magma velocity (Manga et al. 2018b) reduced the magma velocity (Fig. 4). It is also possible that GP290, and other clasts that display textural banding, were generated during a later stage of the GP-forming phase as the eruption waned. Lower upward velocities at the conduit wall, gas loss, and the presence of cooler magma would allow for extended microlite crystallization (Manga et al. 2018b; Sano and Toramaru 2017), as seen throughout GP290. Higher velocity and $d P / d t$ in the conduit center, and melt viscosities $<10^{7} \mathrm{~Pa} \mathrm{~s}$ (due to limited volatile exsolution under hydrostatic pressure) could still allow for melt domains to mingle in the shallow conduit where more viscous microlite-rich magma could be assimilated into the microlite-poor central magma body resulting in textural banding (Fig. 10b). Variable magma ascent velocities may have induced larger-scale velocity shear instabilities (e.g., Kelvin-Helmholtz instabilities) within the shallow conduit over a longer period (Bergantz 2000; Costa and Macedonio 2003). Mingling of the different melt domains may also have occurred above the vent prior to non-explosive fragmentation (Manga et al. 2018a). Interactions with seawater could create a spatially complex thermal gradient within the erupted magma (Mitchell et al. 2018a; Rotella et al. 2013). Cooling models, quench depths, and the identification of posteruptive vesicle growth in this study show that GP magma did not quench instantly (cf. Fauria and Manga 2018; Mitchell et al. 2018a).

The sharp interfaces in microlite number density between adjacent microlite-poor and microlite-rich bands (Fig. $5 \&$ Online Resource 7), and a lack of changes in vesicle size distribution and vesicle shape between bands does not suggest microlite crystallization as a result of shear-localized degassing. Degassing and induced microlite crystallization has been shown to occur in small regions of high strain within the conduit (Kushnir et al. 2017). However, we observe no consistent elongation of vesicles exclusive to the gray bands as we do within the tube pumice samples. The complex framework and frequency of gray bands throughout GP290 implies the mingling of two different magma textures as opposed to the in situ development of shear localization bands.

\section{Giant pumice in the water column: fragmentation and ascent}

Fragmentation by cooling-joint propagation has been suggested to generate large pumice clasts that separate, rise, and settle through the water column, preserving meter-scale textural diversity (Manga et al. 2018a). Large perpendicular vesicles observed in GP290 (Fig. 3g) imply vesicle extension from strain in the conduit or during effusion, a feature also observed in vesicular bands of obsidian flows (Fink 1983; Gonnermann and Manga 2005b; Shields et al. 2016; Tuffen and Castro 2009). This supports the inferred "effusive" eruption mechanism for GP described by Manga et al. (2018a). A lack of destructive fragmentation in the conduit permits large regions of tube vesicles to be preserved in giant pumices with 
lineated fabrics throughout the clast (Figs. 1e and 3c). Giant tube pumices are rare in subaerial explosive eruptions as strain rates in regions of high vesicle shear usually fragment magma efficiently with tube vesicles and elongate permeable pathways (Dingwell et al. 2016; Wright et al. 2006). Greater length scales of observations of magma heterogeneity in the shallow conduit at Havre could, thus, be an analogue for the deeper conduit dynamics in subaerial silicic systems at equivalent pressures. It is possible that textural analysis of deep submarine pumices could provide a secondary window into deeper regions of subaerial silicic conduits and the distribution of large vesicles in pumice.

The presence of a large, vapor-rich submarine plume or hot seawater sheath at Havre was speculated to control the cooling rates of giant pumices in the water column by Mitchell et al. (2018a). Many clasts from the 2012 Havre eruption were found to have cooled through the glass transition at very shallow depths by Mitchell et al. (2018a) and Rotella et al. (2013). In addition, modeling by Manga et al. (2018a) and Fauria and Manga (2018) demonstrated that rise time to the ocean surface was rapid $(<10 \mathrm{~min}$ ) for clasts larger than $10-20 \mathrm{~cm}$. Thus, continued decompression during ascent through the water column would have enabled exsolution and, hence, allowed vesicles to continue to expand; as observed in pumice interiors from other submarine pumice-producing eruptions, e.g., Macauley and Raoul Volcano (Rotella et al. 2013). The high permeability of some giant pumices analyzed here (Fig. 4) may reduce the effects of gas expansion within vesicles, as gas may escape quickly and ingested water can accelerate pumice cooling (Fauria et al. 2017; Fauria and Manga 2018; Manga et al. 2018a; Rust and Cashman 2011). Observations of bread-crusted exteriors in some giant pumices, however, imply that some clast interiors were able to expand faster than permeable gas loss (Fig. 1h). This would have occurred in clasts with lower interior vesicularity, connectivity, and permeability.

A lack of rapidly quenched, dense rinds in all 29 giant pumices could also suggest that the exteriors sampled were not in fact original brittle fragmentation surfaces in contact with seawater, but instead surfaces ensuing from secondary fragmentation and breakup of clasts (cf. Mitchell et al. 2018b) in the water column (Rotella et al. 2013), or clasts from the center of the effusive body. Large fractures that transgress entire clasts demonstrate the fragility of some of these blocks (Figs. 1e, f and 3h, j). Thus, the giant pumice exteriors we sample are not necessarily representative of surfaces generated by brittle fragmentation as proposed for this eruption by Manga et al. (2018a). Examples such as the bread-crusted exterior (Fig. 1h) may be more representative of original fragmentation surfaces. For lower intensity submarine pumice formation and fragmentation from the spalling and autobrecciation of a vesicular carapace (Rotella et al. 2013; Shea et al. 2013; Von Lichtan et al. 2016; White et al. 2001), there is a greater likelihood that the original fragmentation surfaces will be preserved.

Giant pumices from the 2012 Havre eruption share some textural similarities with the giant pumices from Taupo and the Sumisu Domes (Allen et al. 2010; Houghton et al. 2010; Von Lichtan et al. 2016). The subaqueous-derived Taupo blocks from shallow depths $(<200 \mathrm{~m})$ have lower vesicularities than GP $(58-73 \%)$, denser rapidly quenched rinds and inferred mass eruption rates of only $\sim 10^{3} \mathrm{~kg} \mathrm{~s}^{-1}$ (Houghton et al. 2010). While the inferred mechanism of autobrecciation of a vesicular dome carapace at Taupo shares similarities with the brittle fragmentation mechanism suggested for Havre, MER differs by up to four orders of magnitude (Manga et al. 2018a, b; Von Lichtan et al. 2016). Giant pumices from Domes B and $\mathrm{C}$ of the Sumisu Dome Complex share many textural $(\sim 77 \%$ vesicularity, tube fabrics on the associated dome carapace) and morphological characteristics (slabby, polyhedral blocks with internal cracks and jointing) with Havre GP blocks (Allen et al. 2010). Sumisu Dome B and C were erupted from depths of 876-1267 m implying similar hydrostatic effects on conduit dynamics and fragmentation to Havre giant pumices. However, a lack of vesicles $>3 \mathrm{~mm}$ across and texturally uniform interiors of Sumisu giant pumices signifies that additional processes are required to explain the textural heterogeneity throughout GP.

The analyses presented here increase the number of detailed studies of subaqueous giant pumice textures, of which there are only a few at present. However, we note that the microtextures observed in GP blocks exhibit only a few characteristics (e.g., vesicle connectivity, vesicle number density) that would define them as deep submarine rather than subaerial. The preservation of a deposit dominated by highly vesicular meter-scale clasts and possible greater abundance of tube pumices may fingerprint a deep submarine eruptive source (Kato, 1987). Inertial $\left(k_{2}\right)$ (and some Darcian $k_{1}$ ) permeability values higher than those defined for explosive eruptions by Degruyter et al. (2012) (Fig. 4b) may also be a textural characteristic of deep submarine giant pumice blocks that cool slowly and continue to decompress and vesiculate in the water column (Mitchell et al. 2018a). This study shows that, despite erupting under many $\mathrm{MPa}$ of hydrostatic pressure, giant pumice from deep submarine silicic eruptions can be more texturally mature than pumice from subaerial silicic explosive 
eruptions due to continued gas exsolution during ascent in the water column.

\section{Conclusion}

The well-preserved deposits of the 2012 Havre eruption provide one of the best-known field sites for studying silicic volcanic activity on the seafloor. Giant pumice blocks provide meter-scale windows into complex shallow conduit dynamics below the main eruptive vent (900 mbsl) and processes in the water column affecting vesiculation. Quantitative analysis of geochemistry and microtextures, coupled with whole-clast observations and a 2D model for magma flow, lead to four main conclusions about the GP phase of the 2012 eruption:

(1) A compositionally homogenous magma supply prevailed throughout the GP phase. No new, geochemically distinct magma was introduced or entrained into the conduit. Instead, textural banding in GP290 was the result of mingling microlite-rich and microlite-poor melt. We find evidence that microlites were generated by late-stage decompression near conduit walls.

(2) Presence of a region with low cumulative strain at the vent-required to keep bubbles from becoming highly deformed - is possible by incorporating a flared shallow conduit with a 50-m radius or by decreasing GP mass eruption rate from $10^{7}$ to $\sim 10^{6} \mathrm{~kg} \mathrm{~s}^{-1}$.

(3) Bread-crusted exteriors, and overprint and deformation of earlier-formed vesicles by later-stage vesicles, imply some giant pumice exteriors experienced postfragmentation vesicle growth as the clasts continued to decompress in the water column. This supports previous models of slow cooling and continued degassing of large pumice blocks to shallow water depths.

(4) Textural analysis across a single meter-scale clast shows that (i) clasts contain vesicle sizes that span over five orders of magnitude, and (ii) vesicle textures are spatially heterogeneous. Large vesicles may be preserved because of the absence of explosive fragmentation and may permit efficient permeable outgassing.

Our study offers new insight into deep submarine conduit dynamics during the 2012 Havre eruption where a number of findings suggest directions for further research. We emphasize the need to quantify the textural, spatial, and temporal relationships between units derived from the same vent, such as the voluminous pumice raft with GP and later eruption of Dome OP, to assess changing conduit dynamics throughout the entire 2012 eruption. Detailed study of microlite nucleation and growth rates in other units could enhance our understanding of late-stage decompression, strain and cooling rates in the shallow conduit, and during buoyant ascent in the deep submarine environment, during such submarine eruptions. This study highlights the importance of determining submarine vent depths to assess hydrostatic pressure controls on the melt properties within the shallow conduit and the consequent textural diversity and maturity of erupted deep-sea pumice.

Acknowledgments This study was funded primarily through an NSF Ocean grant: OCE-1357443 (SJM, BFH and RJC). MM is supported by NSF EAR 1447559. The $\mu$ XRT analysis was performed at the Lawrence Berkeley National Lab Advanced Light Source beamline 8.3.2 and the large CT scan by SAS at the University of Texas Austin micro-CT facility. Capillary flow porometry and He-pycnometry were assisted by TG and MRJ at the University of Oregon. Microprobe analysis was conducted at the University of Hawai'i at Mānoa. CEC was supported by post-doctoral research fellowship from the Japan Society for the Promotion of Science (JSPS16788). We would like to thank Kenichiro Tani, Takashi Sano, and Eric Hellebrand for their assistance with geochemical data acquisition, JoAnn Sinton and Wagner Petrographic for thin section preparation, Zachary Langdalen for binary processing of BSE images, Warren M. McKenzie for measuring clast densities, and Dula Parkinson for guidance with the $\mu$ XRT imaging. We further acknowledge the full scientific team, crew and Jason ROV team (Woods Hole Oceanographic Institute) aboard the R/V Roger Revelle (Scripps Institute of Oceanography) during the MESH expedition in 2015 , without whom, this study would not have been possible. Finally, we thank Andrew Harris, Katharine Cashman, Lucia Gurioli and an anonymous reviewer for their insightful and helpful reviews of the manuscript.

\section{Appendices}

\section{Appendix 1. Prolate geometry 3D stereo-conversions}

For the prolate 3D stereo-conversion of sheared and tube vesicles, we used the same calculation steps from Sahagian and Proussevitch (1998) as in Online Resource 4, but by applying intersection probabilities $(P)$ and conversion coefficients $(\alpha)$ to the smallest 12 classes of vesicle sizes. This accounted for all vesicles from 2.4 to $38 \mu \mathrm{m}$. Larger vesicles were not included or counted towards in the revised $\mathrm{N}_{\mathrm{Vm}}$ values as they present a negligible addition to total $\mathrm{N}_{\mathrm{Vm}}$ in either case. For $\mathrm{N}_{\mathrm{Vi}}$ calculations, $\mathrm{N}_{\mathrm{Ai}}$ remains the same but $\mathrm{V}_{\mathrm{Hi}}$ (the projected mean height of a vesicle with the equivalent equant volume) changes depending on the vesicle geometry assumed.

Three vesicle geometries were suitable and available from Sahagian and Proussevitch (1998): prolate vesicle with dimensions of $1: 1: 2,1: 2: 5$, and 1:3:10. We applied the appropriate conversions to tube and regular giant pumice vesicles $<$ $38 \mu \mathrm{m}$ in diameter based on macrotextural and microtextural 


\begin{tabular}{|c|c|c|c|c|c|c|c|c|}
\hline \multirow{2}{*}{$\begin{array}{l}\text { Class \# } \\
\text { Geometry }\end{array}$} & \multicolumn{4}{|c|}{ Intersection probability $(P)$} & \multicolumn{4}{|c|}{ Conversion coefficient $(\alpha)$} \\
\hline & Sphere & $1: 1: 2$ & $1: 2: 5$ & $1: 3: 10$ & Sphere & $1: 1: 2$ & $1: 2: 5$ & $1: 3: 10$ \\
\hline 1 (largest) & 60.749 & 31.700 & 1.760 & 0.349 & 1.646 & 3.151 & 3.151 & 3.151 \\
\hline 2 & 16.833 & 43.370 & 14.181 & 2.602 & 0.456 & 4.305 & 7.052 & 38.43 \\
\hline 3 & 8.952 & 17.467 & 41.317 & 12.264 & 0.116 & 4.149 & 20.54 & 181.1 \\
\hline 4 & 5.200 & 5.374 & 37.077 & 25.122 & 0.041 & 3.833 & 41.42 & 482.5 \\
\hline 5 & 3.134 & 1.239 & 4.570 & 49.266 & 0.017 & 3.560 & 69.24 & 1253 \\
\hline 6 & 1.925 & 0.459 & 0.774 & 9.262 & 0.0078 & 3.335 & 99.6 & 4540 \\
\hline 7 & 1.195 & 0.195 & 0.211 & 0.756 & 0.0037 & 3.128 & 121.7 & 17,000 \\
\hline 8 & 0.747 & 0.084 & 0.072 & 0.193 & 0.0018 & 2.934 & 114.3 & 62,000 \\
\hline 9 & 0.468 & 0.039 & 0.026 & 0.064 & 0.0009 & 2.750 & 43.62 & 200,000 \\
\hline 10 & 0.294 & 0.018 & 0.010 & 0.021 & 0.0004 & 2.579 & 137.0 & 670,000 \\
\hline 11 & 0.185 & 0.008 & 0.003 & 0.009 & 0.0002 & 2.418 & 481.8 & $2,300,000$ \\
\hline 12 & 0.117 & 0.004 & 0.001 & 0.003 & 0.0001 & 2.267 & 1036 & $8,100,000$ \\
\hline
\end{tabular}

observations, and from the results of vesicle aspect ratios of the 3D XRT analysis (see Online Resource 5).

$P$ and $\alpha$ values for the three prolate and spherical geometries are as given directly from Sahagian and Proussevitch (1998):

For each vesicle geometry, the new $\mathrm{V}_{\mathrm{Hi}}$ values are calculated by converting the observed bin values into equivalent diameters $(E q D)$ for a sphere assuming the observed diameter $\left(D_{A i}\right)$ is the cross section of the smallest axis of a prolate vesicle:

$$
\begin{aligned}
& E q D_{i(1: 1: 2)}=\left(2 D_{A i}{ }^{3}\right)^{\frac{1}{3}} \\
& E q D_{i(1: 2: 5)}=\left(10 D_{A i}{ }^{3}\right)^{\frac{1}{3}} \\
& E q D_{i(1: 3: 10)}=\left(30 D_{A i}{ }^{3}\right)^{\frac{1}{3}}
\end{aligned}
$$

$\mathrm{V}_{\mathrm{Hi}}$ values are calculated as per Online Resource 4 using the conventional methods of the stereo-conversion to determine final $\mathrm{N}_{\mathrm{Vm}}$ values. Individual $\mathrm{N}_{\mathrm{Vi}}$ values were discounted if negative.

Suitability of the chosen vesicle geometry, e.g., $1: 3: 10$, for a single sample could be confirmed by comparing the modal vesicle diameter from the 2D BSE images with the modal $\mathrm{N}_{\mathrm{Vi}}$ diameter after the $3 \mathrm{D}$ stereo-conversion $\left(D_{3 V}\right)$. For tube vesicles, $D_{A i}$ will be significantly smaller than $D_{3 V}$ unless the prolate stereoconversion is applied. By testing all three geometries, the best geometry to use was where $D_{A i} \approx D_{3 v}$. For tube vesicles, the appropriate geometry was $1: 3: 10$, and regular $=1: 1: 2$. This is the key parameter to change for the non-spherical stero-conversion.
There are caveats with this modification of the Sahagian and Proussevitch (1998) stereo-conversion. Accurate VVDs cannot be determined after stereo-conversion of tube vesicles, as calculated-equant tube vesicle sizes do not correspond to the original vesicle bin sizes of the large vesicles, and so there is not a smooth transition from smaller to larger vesicles outside of the 12 classes. Aspect ratio of vesicles varies with size, as seen in Online Resource 5. Smaller vesicles are likely to undergo less deformation if nucleated at a later stage in the conduit. It is very complicated to apply a varying vesicle geometry across the bin classifications as conversion coefficients are looped calculations based on adjacent geometric bins. By exploring several vesicle geometries, we can see the effect that different aspect ratios may have on number density. We aim to show that, by applying prolate geometries, the obtained $\mathrm{N}_{\mathrm{Vm}}$ values obtained for tube pumices are reduced by an order of magnitude and roughly match those observed in banded and regular giant pumices (Fig. 7). Sahagian and Proussevitch (1998) do assume random vesicle orientation in tube calculations; however, changing this has minimal effect on the final values calculated.

\section{Appendix 2. 2D conduit deformation model}

The deformation model developed to assess vesicle shearing and expected aspect ratios was based on the results of the conduit ascent model for Havre in Manga et al. (2018a) (see Online Resource 10). This 1D two-phase steady flow model was modified from Degruyter et al. (2012) and Kozono and Koyaguchi (2009). These models were developed on the basis of other fundamental conduit ascent models (Slezin 2003; Wilson 1980; Yoshida and Koyaguchi 1999). 
The model calculates the magma pressure, viscosity $(\mu)$, velocity $(u)$, strain rate $(\dot{\gamma})$, and gas fraction $(\phi)$ for a set of pre-determined parameters (Manga et al. 2018a). Vesicle size $\left(x_{b}\right)$ is calculated based on an input vesicle number density of $2.5 \times 10^{8} \mathrm{~cm}^{-3}$ (Table 2) as an average for the giant pumice $\mathrm{N}_{\mathrm{Vm}}$ data from the results:

$x_{b}=\left(\frac{3 \phi}{4 \pi(1-\phi) N_{V m}}\right)^{1 / 3}$

The model runs from pressures of 200 to $9 \mathrm{MPa}$ (determined from the saturation pressure of volatile concentrations in melt inclusions - $5.8 \mathrm{wt} \% \mathrm{H}_{2} \mathrm{O}$ - and the vent depth) over a conduit $8100 \mathrm{~m}$ deep in depth steps of $5 \mathrm{~m}(z)$. Crystallinity is 0.05 (Carey et al. 2018).

Viscosity, gas fraction, pressure, and vesicle size remain constant over the conduit width $\left(R_{C}\right)$. We assume two values for conduit radii (25 and $50 \mathrm{~m}$ ) with a constant mass discharge rate of $10^{7} \mathrm{~kg} \mathrm{~s}^{-1}$ (Carey et al. 2018; Manga et al. 2018a). We chose $50 \mathrm{~m}$ to assess the possibility of a flaring shallow conduit on the strain approaching the vent; the doubling of the conduit radius required a reduction of the mean velocity by a factor of four for conservation of mass. In the laminar regime, the velocity $(u)$ profile (B2) follows a simple parabolic (Llewellin and Manga 2005):

$u(r, z)=u_{l}(z)\left(1-\frac{r^{2}}{R_{C}^{2}}\right)$

where $R_{C}$ is the conduit radius and $r$ is the distance from the conduit center. Subscripts $g$ and $l$ denote gas and liquid phases; the calculated melt and gas velocities were very similar for the Havre conditions, i.e., the bubbles remain coupled to the melt (Manga et al. 2018a). Shear strain rate $(\dot{\gamma})$ across the conduit was calculated from (e.g., Llewellin and Manga 2005):

$\dot{\gamma}(r, z)=\frac{4 u(r, z) r}{R_{C}^{2}}$

The maximum Reynolds number at the conduit center $(\mathrm{Re})$ calculated throughout the conduit ( $\mathrm{Re}<100$ at all depths) supports our use of a laminar velocity profile:

$\operatorname{Re}(z)=2 u_{l}(z) R_{c} \frac{\left(\phi(z) \rho_{g}(z)+(1-\phi(z)) \rho_{l}(z)\right)}{\left(\phi(z) \mu_{g}(z)+(1-\phi(z)) \mu_{l}(z)\right)}$

The maximum upward velocity $\left(u_{\max }\right)$ and radial velocity across the conduit $\left(u_{r}\right)$ was calculated at all depths using the mean liquid velocity $\left(u_{l}\right)$ from Manga et al. (2018a). Strain at each point in the conduit was calculated from:

$\gamma(r, z)=\int^{z} \frac{\gamma(r, z)}{u_{l}(r, z)} \cdot d z$
The capillary number $(\mathrm{Ca})$, ratio of bubble shearing to relaxation timescales, was calculated across the $2 \mathrm{D}$ conduit for a single evolving bubble size $\left(x_{b}\right)$ through the conduit. We assume constant bubble number density due to the very low crystallinity, using a bubble surface tension $(\sigma)$ for rhyolite of $0.075 \mathrm{~N} \mathrm{~m}^{-1}$ (Shea 2017). We then used Ca, and the deformation models of Canedo et al. (1993) and Rust and Manga (2002), and basic geometric relations to determine the maximum expected bubble aspect ratios (AR) where AR is the ratio of the longest to shortest bubble axis.

$$
\begin{aligned}
\mathrm{Ca}(r, z) & =\frac{x_{b}(z) \dot{\gamma}(r, z) \mu_{l}(r, z)}{\sigma} \\
A R(r, z) & =5.46\left(\frac{x_{b}(z) \dot{\gamma}(r, z) \mu_{l}(r, z)}{\sigma}\right)^{0.645} \\
& =5.46 \mathrm{Ca}(r, z)^{0.645}
\end{aligned}
$$

A heterogeneous assumption (lower surface tension $0.02 \mathrm{~N} \mathrm{~m}^{-1}$ - Shea 2017) would only increase AR by a factor of $\sim 2.4$. Decompression rate $(d P / d t)$ as a function of lateral position across the conduit was calculated using the obtained pressure gradient (Manga et al. 2018a):

$\frac{d P}{d t}(r, z)=u_{z} \frac{\partial P}{\partial z}$

Open Access This article is distributed under the terms of the Creative Commons Attribution 4.0 International License (http:// creativecommons.org/licenses/by/4.0/), which permits unrestricted use, distribution, and reproduction in any medium, provided you give appropriate credit to the original author(s) and the source, provide a link to the Creative Commons license, and indicate if changes were made.

\section{References}

Adams NK, Houghton BF, Fagents SA, Hildreth W (2006) The transition from explosive to effusive eruptive regime: the example of the 1912 Novarupta eruption, Alaska. Geol Soc Am Bull 118(5-6):620-634. https://doi.org/10.1130/B25768.1

Allen SR, McPhie J (2009) Products of neptunian eruptions. Geology 37(7):639-642. https://doi.org/10.1130/G30007A.1

Allen SR, Fiske RS, Tamura Y (2010) Effects of water depth on pumice formation in submarine domes at Sumisu, Izu-Bonin arc, western Pacific. Geology 38(5):391-394. https://doi.org/10.1130/G30500.1

Aravena A, Cioni R, de Michieli Vitturi M, Pistolesi M, Ripepe M, Neri A (2018) Evolution of conduit geometry and eruptive parameters during effusive events. Geophys Res Lett. https://doi.org/10.1029/ 2018GL077806

Barker SJ, Rotella MD, Wilson CJ, Wright IC, Wysoczanski RJ (2012) Contrasting pyroclast density spectra from subaerial and submarine silicic eruptions in the Kermadec arc: implications for eruption processes and dredge sampling. Bull Volcanol 74(6):1425-1443. https://doi.org/10.1007/s00445-012-0604-2 
Bergantz GW (2000) On the dynamics of magma mixing by reintrusion: implications for pluton assembly processes. J Struct Geol 22(9): 1297-1309. https://doi.org/10.1016/S0191-8141(00)00053-5

Blundy J, Cashman K (2008) Petrologic reconstruction of magmatic system variables and processes. Rev Mineral Geochem 69(1):179-239. https://doi.org/10.2138/rmg.2008.69.6

Brugger CR, Hammer JE (2010a) Crystal size distribution analysis of plagioclase in experimentally decompressed hydrous rhyodacite magma. Earth Planet Sci Lett 300(3-4):246-254. https://doi.org/ 10.1016/j.epsl.2010.09.046

Brugger CR, Hammer JE (2010b) Crystallization kinetics in continuous decompression experiments: implications for interpreting natural magma ascent processes. J Petrol 51(9):1941-1965. https://doi.org/ 10.1093/petrology/egq044

Burgisser A, Chevalier L, Gardner JE, Castro JM (2017) The percolation threshold and permeability evolution of ascending magmas. Earth Planet Sci Lett 470:37-47. https://doi.org/10.1016/j.epsl.2017.04. 023

Canedo EL, Favelukis M, Tadmor Z, Talmon Y (1993) An experimental study of bubble deformation in viscous liquids in simple shear flow. AIChE J 39(4):553-559. https://doi.org/10.1002/aic.690390403

Carey RJ, Houghton BF, Thordarson T (2009) Abrupt shifts between wet and dry phases of the 1875 eruption of Askja volcano: microscopic evidence for macroscopic dynamics. J Volcanol Geotherm Res 184(3-4):256-270

Carey RJ, Wysoczanski R, Wunderman R, Jutzeler M (2014) Discovery of the largest historic silicic submarine eruption. EOS Trans Am Geophys Union 95(19):157-164. https://doi.org/10.1002/ 2014EO190001

Carey RJ, Soule SA, Manga M, White JDL, McPhie J, Wysoczanski R, Jutzeler M, Tani K, Fornari D, Caratori-Tontini F, Houghton BF, Mitchell SJ, Ikegami F, Conway C, Murch A, Fauria K, Jones M, Cahalan R, McKenzie W (2018) The largest deep-ocean silicic volcanic eruption of the past century. Sci Adv 4(1):e1701121. https:// doi.org/10.1126/sciadv.1701121

Cas RA, Giordano G (2014) Submarine volcanism: a review of the constraints, processes and products, and relevance to the Cabo de Gata volcanic succession. Ital J Geosci 133(3):362-377. https://doi.org/ 10.3301/IJG.2014.46

Cas RA, Simmons J (2018) Why deep-water eruptions are so different from subaerial eruptions. Front Earth Sci 6:198. https://doi.org/10. 3389/feart.2018.00198

Cashman KV, Scheu B (2015) Magmatic fragmentation. In: Sigurdsson H, Houghton B, McNutt S, Rymer H, Stix J (eds) The Encyclopedia of volcanoes, 2nd edn. Academic Press, San Diego, pp 459-471. https://doi.org/10.1016/B978-0-12-385938-9.00025-0

Cluzel N, Laporte D, Provost A, Kannewischer I (2008) Kinetics of heterogeneous bubble nucleation in rhyolitic melts: implications for the number density of bubbles in volcanic conduits and for pumice textures. Contrib Mineral Petrol 156(6):745-763. https://doi.org/ 10.1007/s00410-008-0313-1

Costa A, Macedonio G (2003) Viscous heating in fluids with temperature-dependent viscosity: implications for magma flows. arXiv preprint physics $/ 0302100$

Degruyter W, Bachmann O, Burgisser A, Manga M (2012) The effects of outgassing on the transition between effusive and explosive silicic eruptions. Earth Planet Sci Lett 349:161-170. https://doi.org/10. 1016/j.eps1.2012.06.056

Dingwell DB, Lavallée Y, Hess KU, Flaws A, Martí Molist J, Nichols AR, Gilg HA, Schillinger B (2016) Eruptive shearing of tube pumice: pure and simple. Solid Earth 7:1383-1393. https://doi.org/10. 5194/se-7-1383-2016

Eichelberger JC, Westrich HR (1981) Magmatic volatiles in explosive rhyolitic eruptions. Geophys Res Lett 8(7):757-760. https://doi. org/10.1029/GL008i007p00757
Fauria KF, Manga M (2018) Pyroclast cooling and saturation in water. J Volcanol Geotherm Res 352:17-31. https://doi.org/10.1016/j. jvolgeores.2018.07.002

Fauria KE, Manga M, Wei Z (2017) Trapped bubbles keep pumice afloat and gas diffusion makes pumice sink. Earth Planet Sci Lett 460:50 59. https://doi.org/10.1016/j.epsl.2016.11.055

Fink JH (1983) Structure and emplacement of a rhyolitic obsidian flow: Little Glass Mountain, Medicine Lake Highland, northern California. Geol Soc Am Bull 94(3):362-380. https://doi.org/10. 1130/0016-7606(1983)94<362:SAEOAR >2.0.CO;2

Giachetti T, Druitt TH, Burgisser A, Arbaret L, Galven C (2010) Bubble nucleation, growth and coalescence during the 1997 Vulcanian explosions of Soufrière Hills volcano, Montserrat. J Volcanol Geotherm Res 193(3):215-231. https://doi.org/10.1016/j. jvolgeores.2010.04.001

Gonnermann HM, Manga M (2003) Explosive volcanism may not be an inevitable consequence of magma fragmentation. Nature 426(6965): 432. https://doi.org/10.1038/nature02138

Gonnermann HM, Manga M (2005a) Nonequilibrium magma degassing: results from modeling of the ca. $1340 \mathrm{AD}$ eruption of Mono Craters, California. Earth Planet Sci Lett 238(1):1-16. https://doi.org/10. 1016/j.eps1.2005.07.021

Gonnermann HM, Manga M (2005b) Flow banding in obsidian: a record of evolving textural heterogeneity during magma deformation. Earth Planet Sci Lett 236(1-2):135-147. https://doi.org/10.1016/j.epsl. 2005.04.031

Gurioli L, Houghton BF, Cashman KV, Cioni R (2005) Complex changes in eruption dynamics during the $79 \mathrm{AD}$ eruption of Vesuvius. Bull Volcanol 67(2):144-159. https://doi.org/10.1007/s00445-004-0368-4

Head JW III, Wilson L (2003) Deep submarine pyroclastic eruptions: theory and predicted landforms and deposits. J Volcanol Geotherm Res 121(3-4):155-193. https://doi.org/10.1016/S0377-0273(02) 00425-0

Houghton BF, Wilson C (1989) A vesicularity index for pyroclastic deposits. Bull Volcanol 51(6):451-462. https://doi.org/10.1007/ BF01078811

Houghton BF, Carey RJ, Cashman KV, Wilson CJ, Hobden BJ, Hammer JE (2010) Diverse patterns of ascent, degassing, and eruption of rhyolite magma during the 1.8 ka Taupo eruption, New Zealand: evidence from clast vesicularity. J Volcanol Geotherm Res 195(1): 31-47. https://doi.org/10.1016/j.jvolgeores.2010.06.002

Janebo MH, Houghton BF, Thordarson T, Larsen G (2016) Shallow conduit processes during the ad 1158 explosive eruption of Hekla volcano, Iceland. Bull Volcanol 78(10):74

Jones MR, Soule SA, Gonnermann HM, Le Roux V, Clague DA (2018) Magma ascent and lava flow emplacement rates during the 2011 axial seamount eruption based on $\mathrm{CO} 2$ degassing. Earth Planet Sci Lett 494:32-41. https://doi.org/10.1016/j.eps1.2018.04.044

Jutzeler M, Marsh R, Carey RJ, White JD, Talling PJ, Karlstrom L (2014) On the fate of pumice rafts formed during the 2012 Havre submarine eruption. Nat Commun 5:3660. https://doi.org/10.1038/ ncomms 4660

Kano K (2003) Subaqueous pumice eruptions and their products: A review. Washington DC American Geophysical Union Geophysical Monograph Series, 140: 213-229. https://doi.org/10.1029/ 140GM14

Kano K, Yamamoto T, Ono K (1996) Subaqueous eruption and emplacement of the Shinjima Pumice, Shinjima (Moeshima) Island, Kagoshima Bay, SW Japan. J Volcanol Geotherm Res 71(2-4): 187-206. https://doi.org/10.1016/0377-0273(95)00077-1

Kato Y (1987) Woody pumice generated with submarine eruption. J Geol Soc Jpn 93:11-20

Klug C, Cashman K, Bacon C (2002) Structure and physical characteristics of pumice from the climactic eruption of Mount Mazama (Crater Lake), Oregon. Bull Volcanol 64(7):486-501. https://doi. org/10.1007/s00445-002-0230-5 
Kozono T, Koyaguchi T (2009) Effects of relative motion between gas and liquid on 1-dimensional steady flow in silicic volcanic conduits: 1. An analytical method. J Volcanol Geotherm Res 180(1):21-36. https://doi.org/10.1016/j.jvolgeores.2008.11.006

Kushnir AR, Martel C, Champallier R, Arbaret L (2017) In situ confirmation of permeability development in shearing bubble-bearing melts and implications for volcanic outgassing. Earth Planet Sci Lett 458:315-326

Llewellin EW, Manga M (2005) Bubble suspension rheology and implications for conduit flow. J Volcanol Geotherm Res 143(1):205-217. https://doi.org/10.1016/j.jvolgeores.2004.09.018

Manga M, Fauria KE, Lin C, Mitchell SJ, Jones M, Conway CE, Degruyter W, Hosseini B, Carey R, Cahalan R, Houghton BF (2018a) The pumice raft-forming 2012 Havre submarine eruption was effusive. Earth Planet Sci Lett 489:49-58. https://doi.org/10. 1016/j.epsl.2018.02.025

Manga M, Mitchell SJ, Degruyter W, Carey RJ (2018b) Transition of eruptive style: pumice raft to dome-forming eruption at the Havre submarine volcano, southwest Pacific Ocean. Geology 46(12): 1075-1078. https://doi.org/10.1130/G45436.1

Mitchell SJ, McIntosh IM, Houghton BF, Carey RJ, Shea T (2018a) Dynamics of a powerful deep submarine eruption recorded in H2O contents and speciation in rhyolitic glass: The 2012 Havre eruption. Earth Planet Sci Lett 494:135-147. https://doi.org/10. 1016/j.epsl.2018.04.053

Mitchell SJ, Biass S, Houghton BF, Anderson A, Bonny E, Walker BH, Mintz BG, Turner NR, Frank D, Carey RJ, Rosenberg MD (2018b) The interplay among clast size, vesicularity, postfragmentation expansion, and clast breakage: an example from the $1.8 \mathrm{ka}$ Taupo eruption. In: Poland M, Garcia M, Camp V, Grunder A (eds) Field volcanology: a tribute to the distinguished career of Don Swanson: Geological Society of America Special Paper, vol. 538. https://doi. org/10.1130/2018.2538(17)

Murch AP, White JD, Carey R (2019) Characteristics and deposit stratigraphy of submarine-erupted silicic ash, Havre volcano, Kermadec Arc, New Zealand. Front Earth Sci 7:1. https://doi.org/10.3389/ feart.2019.00001

Papale P (1999) Strain-induced magma fragmentation in explosive eruptions. Nature 397(6718):425-428. https://doi.org/10.1038/ 17109

Polacci M, Papale P, Rosi M (2001) Textural heterogeneities in pumices from the climactic eruption of mount Pinatubo, 15 June 1991, and implications for magma ascent dynamics. Bull Volcanol 63:83-97. https://doi.org/10.1007/s004450000123

Polacci M, Papale P, Del Seppia D, Giordano D, Romano C (2004) Dynamics of magma ascent and fragmentation in trachytic versus rhyolitic eruptions. J Volcanol Geotherm Res 131(1-2):93-108. https://doi.org/10.1016/S0377-0273(03)00319-6

Polacci M, Baker DR, Mancini L, Tromba G, Zanini F (2006) Threedimensional investigation of volcanic textures by X-ray microtomography and implications for conduit processes. Geophys Res Lett 33(13)

Risso C, Scasso RA, Aparicio A (2002) Presence of large pumice blocks on Tierra del Fuego and South Shetland Islands shorelines, from 1962 South Sandwich Islands eruption. Mar Geol 186(3):413-422. https://doi.org/10.1016/S0025-3227(02)00190-1

Rotella MD, Wilson CJ, Barker SJ, Wright IC (2013) Highly vesicular pumice generated by buoyant detachment of magma in subaqueous volcanism. Nat Geosci 6(2):129-132. https://doi.org/10.1038/ ngeo1709

Rotella MD, Wilson CJ, Barker SJ, Schipper CI, Wright IC, Wysoczanski RJ (2015) Dynamics of deep submarine silicic explosive eruptions in the Kermadec arc, as reflected in pumice vesicularity textures. J Volcanol Geotherm Res 301:314-332. https://doi.org/10.1016/j. jvolgeores.2015.05.021
Rust AC, Cashman KV (2004) Permeability of vesicular silicic magma: inertial and hysteresis effects. Earth Planet Sci Lett 228(1):93-107. https://doi.org/10.1016/j.epsl.2004.09.025

Rust AC, Cashman KV (2011) Permeability controls on expansion and size distributions of pyroclasts. J Geophys Res Solid Earth 116. https://doi.org/10.1029/2011JB008494

Rust AC, Manga M (2002) Bubble shapes and orientations in low Re simple shear flow. J Colloid Interface Sci 249(2):476-480. https:// doi.org/10.1006/jcis.2002.8292

Saar MO, Manga M (1999) Permeability-porosity relationship in vesicular basalts. Geophys Res Lett 26(1):111-114. https://doi.org/10. 1029/1998GL900256

Sahagian DL, Proussevitch AA (1998) 3D particle size distributions from 2D observations: stereology for natural applications. J Volcanol Geotherm Res 84(3-4):173-196. https://doi.org/10.1016/S03770273(98)00043-2

Sano K, Toramaru A (2017) Cooling and crystallization of rhyoliteobsidian lava: insights from micron-scale projections on plagioclase microlites. J Volcanol Geotherm Res 341:158-171. https://doi.org/ 10.1016/j.jvolgeores.2017.05.012

Schipper CI, White JD, Houghton BF (2010a) Syn-and post-fragmentation textures in submarine pyroclasts from Lōihi seamount, Hawaii. J Volcanol Geotherm Res 191(1-2):93-106. https://doi.org/10. 1016/j.jvolgeores.2010.01.002

Schipper CI, White JD, Houghton BF, Shimizu N, Stewart RB (2010b) "Poseidic" explosive eruptions at Loihi seamount, Hawaii. Geology 38(4):291-294. https://doi.org/10.1130/G30351.1

Schipper CI, White JD, Houghton BF, Shimizu N, Stewart RB (2010c) Explosive submarine eruptions driven by volatile-coupled degassing at Lōihi seamount, Hawaii. Earth Planet Sci Lett 295(3-4):497-510. https://doi.org/10.1016/j.epsl.2010.04.031

Shea T (2017) Bubble nucleation in magmas: a dominantly heterogeneous process? J Volcanol Geotherm Res 343:155-170. https://doi. org/10.1016/j.jvolgeores.2017.06.025

Shea T, Houghton BF, Gurioli L, Cashman KV, Hammer JE, Hobden BJ (2010) Textural studies of vesicles in volcanic rocks: an integrated methodology. J Volcanol Geotherm Res 190:271-289. https://doi. org/10.1016/j.jvolgeores.2009.12.003

Shea T, Gurioli L, Houghton BF (2012) Transitions between fall phases and pyroclastic density currents during the AD 79 eruption at Vesuvius: building a transient conduit model from the textural and volatile record. Bull Volcanol 74(10):2363-2381. https://doi.org/10. 1007/s00445-012-0668-Z

Shea T, Hammer J, First E (2013) Magma balloons or bombs? Nat Geosci 6(10):802. https://doi.org/10.1038/ngeo1971

Shea T, Hellebrand E, Gurioli L, Tuffen H (2014) Conduit-to localizedscale degassing during Plinian eruptions: insights from major element and volatile $(\mathrm{Cl}$ and $\mathrm{H} 2 \mathrm{O})$ analyses within Vesuvius $\mathrm{AD} 79$ pumice. J Petrol 55(2):315-344. https://doi.org/10.1093/petrology/ egt069

Shields JK, Mader HM, Caricchi L, Tuffen H, Mueller S, Pistone M, Baumgartner L (2016) Unravelling textural heterogeneity in obsidian: shear-induced outgassing in the Rocche Rosse flow. J Volcanol Geotherm Res 310:137-158. https://doi.org/10.1016/j.jvolgeores. 2015.12 .003

Slezin YB (2003) The mechanism of volcanic eruptions (a steady state approach). J Volcanol Geotherm Res 122(1-2):7-50. https://doi.org/ 10.1016/S0377-0273(02)00464-X

Thomas N, Jaupart C, Vergniolle S (1994) On the vesicularity of pumice. J Geophys Res 99(B8):15,633-15,644. https://doi.org/10.1029/ 97JB00622

Toramaru A (2006) BND (bubble number density) decompression rate meter for explosive volcanic eruptions. J Volcanol Geotherm Res 154(3-4):303-316. https://doi.org/10.1016/j.jvolgeores.2006.03. 027 
Toramaru A (2014) On the second nucleation of bubbles in magmas under sudden decompression. Earth Planet Sci Lett 404:190-199. https://doi.org/10.1016/j.epsl.2014.07.035

Toramaru A, Noguchi S, Oyoshihara S, Tsune A (2008) MND (microlite number density) water exsolution rate meter. J Volcanol Geotherm Res 175(1-2):156-167. https://doi.org/10.1016/j.jvolgeores.2008. 03.035

Tuffen H, Castro JM (2009) The emplacement of an obsidian dyke through thin ice: Hrafntinnuhryggur, Krafla Iceland. J Volcanol Geotherm Res 185(4):352-366. https://doi.org/10.1016/j. jvolgeores.2008.10.021

Van Otterloo J, Cas RA, Scutter CR (2015) The fracture behaviour of volcanic glass and relevance to quench fragmentation during formation of hyaloclastite and phreatomagmatism. Earth Sci Rev 151:79 116. https://doi.org/10.1016/j.earscirev.2015.10.003

Von Lichtan IJ, White JDL, Manville V, Ohneiser C (2016) Giant rafted pumice blocks from the most recent eruption of Taupo volcano, New Zealand: insights from palaeomagnetic and textural data. J Volcanol Geotherm Res 318:73-88. https://doi.org/10.1016/j.jvolgeores. 2016.04.003

White JD, Manville V, Wilson CJN, Houghton BF, Riggs NR, Ort M (2001) Settling and deposition of AD 181 Taupo pumice in lacustrine and associated environments. Volcaniclastic sedimentation in lacustrine settings. White JDL, Riggs NR (eds) pp 141-150. https:// doi.org/10.1002/9781444304251.ch7

White JD, Schipper CI, Kano K (2015) Submarine explosive eruptions. In The encyclopedia of volcanoes: 553-569. Academic Press. https:// doi.org/10.1016/B978-0-12-385938-9.00031-6
Whitham AG, Sparks RSJ (1986) Pumice. Bull Volcanol 48(4):209-223. https://doi.org/10.1007/BF01087675

Wilson L (1980) Relationships between pressure, volatile content and ejecta velocity in three types of volcanic explosion. J Volcanol Geotherm Res 8(2-4):297-313. https://doi.org/10.1016/03770273(80)90110-9

Wilson CJN (1993) Stratigraphy, chronology, styles and dynamics of late Quaternary eruptions from Taupo volcano, New Zealand. Phil Trans R Soc Lond A 343(1668):205-306

Wright HM, Weinberg RF (2009) Strain localization in vesicular magma: implications for rheology and fragmentation. Geology 37(11):10231026

Wright IC, Gamble JA, Shane PA (2003) Submarine silicic volcanism of the Healy caldera, southern Kermadec arc (SW Pacific): Ivolcanology and eruption mechanisms. Bull Volcanol 65(1):15-29

Wright H, Roberts JJ, Cashman KV (2006) Permeability of anisotropic tube pumice: model calculations and measurements. Geophys Res Lett 33(17). https://doi.org/10.1029/2006GL027224

Wright HM, Cashman KV, Gottesfeld EH, Roberts JJ (2009) Pore structure of volcanic clasts: measurements of permeability and electrical conductivity. Earth Planet Sci Lett 280(1-4):93-104. https://doi.org/ 10.1016/j.epsl.2009.01.023

Yoshida S, Koyaguchi T (1999) A new regime of volcanic eruption due to the relative motion between liquid and gas. J Volcanol Geotherm Res 89(1-4):303-315. https://doi.org/10.1016/S0377-0273(99) 00005-0 